The Future in Stone: Architecture as Expression of National Socialist Temporality

By

Alex Wilkinson Cruddas

A thesis submitted to the Faculty of Graduate and Postdoctoral Affairs in partial fulfillment of the requirements for the degree of

\title{
Master of Arts
}

In

History

\author{
Department of History \\ Carleton University \\ Ottawa, Canada
}

(C) 2016

Alex Wilkinson Cruddas 


\begin{abstract}
Working alongside Adolf Hitler, architect Albert Speer pioneered his theory of Ruinenwert, or "ruin value", which was employed in the design of monumental architectural projects. These structures were designed to evoke imagery of the Nazi's contemporary power and ideology and were created to function as lieux de mémoire ("places of memory") for subsequent generations of Aryans, providing heroic ruins for a future audience imagined as both bearers of the regime's cultural legacy and witness to its destruction. The regime itself was understood to possess the contradictory qualities of the eternal and terminal, and its architecture was to reflect this. Little attention has been given to contextualizing the architecture of temporality National Socialism within the regime's greater culture of future-mindedness. This work seeks to establish connections between existing discussions of National Socialist architectural futurity and those that explore the regime's fascination with its own future more broadly.
\end{abstract}




\section{Acknowledgments}

I would firstly like to thank the wonderful and dedicated History Department administrative staff, particularly Joan White, whose support and assistance over the past years was immeasurable. My sincere thanks go to you Joan. I would also like to thank my readers, Dr. Casteel and Dr. Elżanowski, for taking the time to read my work and for being a valued part of my thesis project.

I would - of course - like to extend my deepest appreciation and thanks to my supervisor Jennifer Evans, whose guidance helped shape my work, and whose inexhaustible patience and advice helped me weather the storm of thesis writing. Words cannot express my gratitude.

I would also like to thank my mother, father, and my grandparents, whose encouragement and support helped me to get to where I am today.

Finally, I would like to thank those people in my life who stood by as stalwart companions during my MA, including all of my peers from the History Department. Of particular note are: Andrew Sopko, Joanne DeCosse, and Kathryn P. Boschmann - three people whose inclusion in my life has been solely enriching and without whom my life would be markedly less enjoyable; Lina Crompton, whose laugh could bring a smile to even the most sullen face; Kellen Wadden - who's wonderful company has kept me sane these past three years; and Meghan Lundrigan, whose friendship, advice, and support has been valuable beyond reason, and whose presence in my life for the past three years has made me a better person. 


\section{Table of Contents}

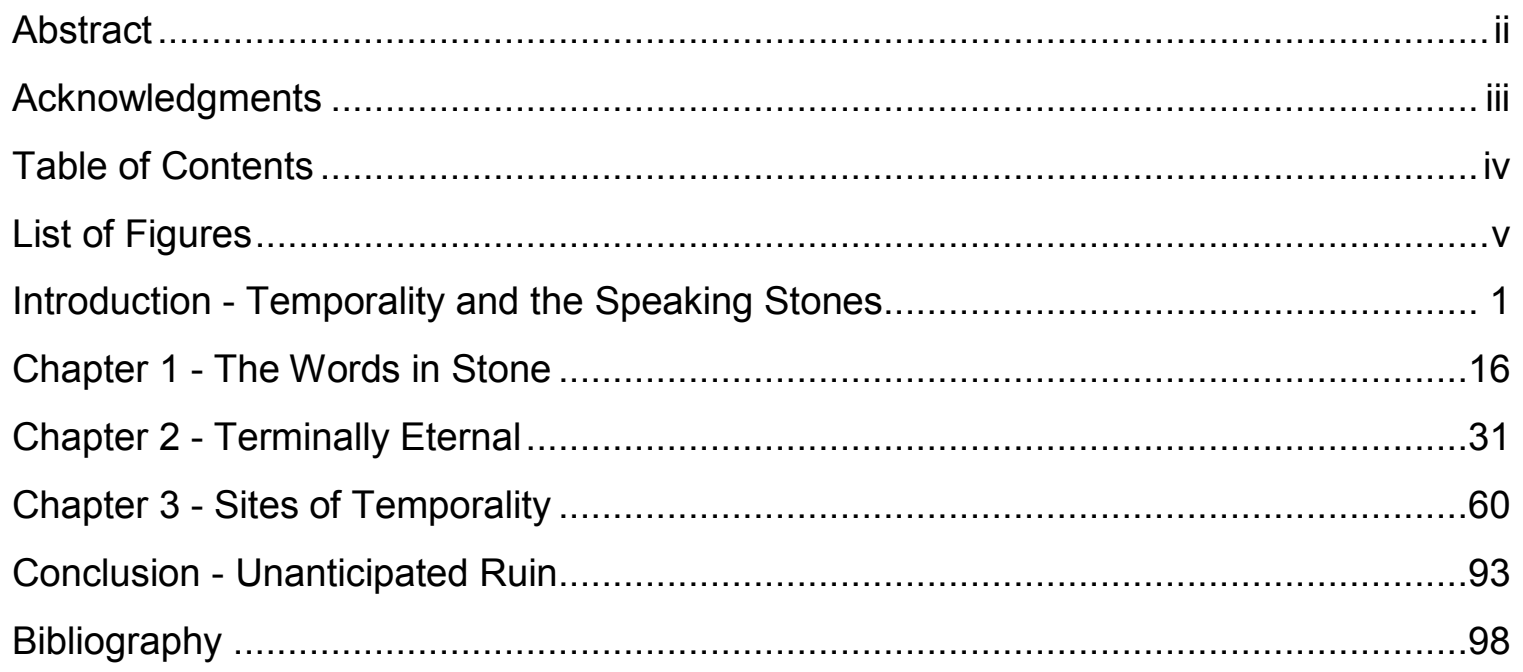




\section{List of Figures}

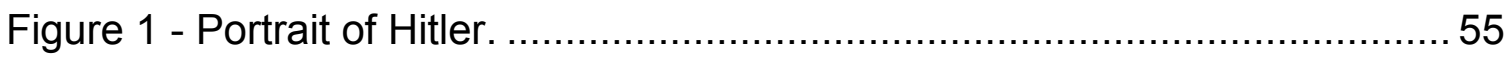

Figure 2 - Portrait of Hitler with religious motifs. ........................................ 56

Figure 3 - A rally at the Reichsparteitagsgelände ......................................... 70

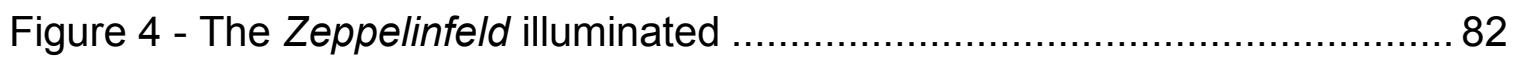

Figure 5 - A model of the proposed Welthauptstadt ...................................... 89

Figure 6 - The start line of the Norisring in Nuremberg.................................. 97 


\section{Introduction - Temporality and the Speaking Stones}

Nestled between a large forested area, the local rail station, and a sports stadium lies the Norisring street circuit in Nuremberg, a popular auto-racing track that boasts both a unique urban landscape and appealing natural features. At the start line of the Norisring sits the ruined remains of the Zeppelinfeld ("Zeppelin Field"), a structure designed by Nazi architect Albert Speer to embody Adolf Hitler's and the National Socialists' vision of an eternal Germanic Reich. In a moment of historical irony, the once dominating structure, which formerly hosted mass political gatherings of over 500000 people, now sits in crumbling dilapidation as a kitsch side piece to local sporting events.

The Zeppelinfeld is only one example of architecture envisioned within the Third Reich. Under the reigns of Albert Speer and the close supervision of Hitler, the National Socialist architectural programme imagined and constructed buildings whose purpose was to extend the regime's cultural hegemony beyond the limits of its present into the distant future. State architecture under National Socialism was a reflection of the grandeur of the party itself, with structures designed by notable Nazi architects like Speer and Paul Troost presenting an outward imitation of existing cultural touchstones, specifically those of ancient Rome and Greece. These buildings were often large and imposing, and offered a stark aesthetic which sought to minimize the viewer against the structure. These structures were imagined within a culture of temporality and historicity which privileged the relationship between space and memory as well as the regime's own subjective understanding of the historical as a malleable truth. Architecture, 
in this sense, served as a tangible reflection of National Socialism's preoccupation with time, and specifically, with a sense of history unbound from culturally subjective narratives. Nazi rhetoric sought to return to an understanding of history and time interwoven as objective and universally constant, a time before - in the words of Richard Terdiman - the "memory crisis" of the post French Revolution period. As Terdiman describes, the crisis arose out of the tumultuous revolutionary period, wherein, "people experienced the insecurity of their culture's involvement with its past[.]"1 Architecture under the NSDAP then acted as pre-emptive lieux de mémoire ("places of memory") which allowed the regime to police its own future history through actions in the present, a process which was only achievable within the existing atmosphere of cultural temporality and historicity that permeated all ideological rhetoric under National Socialism. Coined by historian Pierre Nora, lieux de mémoire are "places, sites, causes" which gain status as lieux de mémoire when they are imbued with cultural importance. "An archive", Nora writes, "is a purely material site that becomes a lieu de mémoire only if imagination invests it with a symbolic aura." ${ }^{2}$

My project examines architecture as a place where Nazi rhetoric shaped the physical landscape in such a way as to promote a vision of an eternal Germanic Reich. While NS architecture has been studied extensively, little attention has been given to those aspects of National Socialist cultural policy that

\footnotetext{
${ }^{1}$ Richard Terdiman, Present Past: Modernity and the Memory Crisis (Cornell University Press, 1993), 3.

2 Pierre Nora and Lawrence D. Kritzman, Realms of Memory: Conflicts and Divisions (Columbia University Press, 1996), 14.
} 
used temporality as a way to co-opt and reimagine existing socio-cultural institutions and entities so as to naturalize and promote the party's authority over subjects and state. I argue that, while attention has been paid in the literature to the use of Nazi architecture as an expression of the regime's desire for longevity, scholars have yet to examine the role of temporality on Nazi conceptions of cultural identity.

I explore this argument in three parts. First, I investigate the current literature's discussions of National Socialist architecture and culture as they relate to historicity and temporality, and show that more emphasis needs to be placed on the relationship between the party's sense and expression of culture and notions of time and historicity. Here I review works from the disciplines of history and architecture as well as cultural studies in order to map how the various disciplines have approached this subject over the last 70 years.

Second, I examine National Socialism's construction of a cultural narrative of temporality through the creation and adoption of future-oriented myths and rhetoric, looking explicitly at how the ideological motives of individual party members and orators helped form a larger narrative of eternality and historic significance. Specifically, I investigate the regime's use of religious iconography and scripture to shape the narrative of National Socialist futurity into one that paralleled traditional Christian eschatological parables. Beyond rhetoric, I also explore the use of historical evidence in the establishment of a cultural history that fit into existing ideological desires. 
Finally, I present specific cases in which the regime's rhetoric of temporality was employed in the design of state-sponsored architectural works. I showcase three specific projects - the Reichsparteitagsgelände ("Nazi party rally grounds") in Nuremberg, the Reichssportfeld in Berlin, as well as the proposed site of Welthauptstadt Germania ("World-capital Germania”), specifically the envisioned location of a First World War Triumphal Arch and the current resting place of the Schwerbelastungskörper ("heavy load-bearing body") in northwestern Tempelhof, Berlin - as exemplars of the regime's emphasis on creating cultural hegemony across time. Here I explore the idea of an "imperial ruin gaze" and the role of ruins themselves as objective-lieux de memoire as described by Julia Hell and Pierre Nora respectively. Here, I will show, the promotion of Nazi aesthetics by contemporary architects is vital to the Reich's own sense of futurity.

As my project focuses on three distinct avenues of interrogation my introduction will forgo the standard analysis of historiography and literature in favour of presenting a conceptual framework. The historiography and literature reviews will be presented within each separate and respective chapter.

In the following pages I address not only these select architectural works, but I also seek to present the larger framework of cultural temporality in which they were imagined. In terms of some of the concepts to be used in this study, I use the terms "temporality," "temporal," and "temporally-inclined" to denote the ways in which an object or idea is rooted in time, while still being part of a greater 
network of events. "Temporal," in the strictest sense, refers to possessing the qualities of, or relating to, time. However, for my work I use this term in keeping with Reinhart Koselleck's understanding of the process of temporalization that is, the sense that time is not easily separated between past, present, and future but that conceptions of time overlap and have a history, and that, for this reason, situating an object or idea in a specific state of time (past, present, or future) is problematic. ${ }^{3}$ National Socialist discourse on futurity provides a case in point. As I will show, the party, via its architecture, wielded fears of present day annihilation as a tool to shape a particular vision of the future. ${ }^{4}$

I employ the term "historicity" to evoke the sense of belonging to history or being aware of something's place within a known or perceived historical record, while "temporality" implies a continuity within a larger field or record. In other words, the temporality of a thing might not define its position within the history of humanity but might even position it within a more mythic scale, beyond the reach of history-minders. In this sense, key players within the National Socialist regime employed a sense of temporality as an objective and universal truth. Sharon Macdonald's work is helpful in fleshing this out insofar as it discusses how audiences interacted with these ideas as well as the authorial intent imbued in the works of National Socialism, particularly the desire to speak with the future on

\footnotetext{
${ }^{3}$ Reinhart Koselleck, Futures Past: On the Semantics of Historical Time, trans. Keith Tribe (New York: Columbia University Press, 2004), 9-12.

4 Julia Hell and Andreas Schönle, Ruins of Modernity (Duke University Press, 2010), 188.
} 
a familiar level. ${ }^{5}$ This process of authorship is one of active historical engagement wherein Nazi architecture was to be established as lieux de memoire, places where memory was focused and concentrated. However, the term lieux de memoire is perhaps not precisely accurate for this context, as Pierre Nora's work on the subject is framed around the creation of subjective cultural memory. Undoubtedly this is what the NSDAP were creating, sites of cultural memory, however if we consider their intent and the self-absorbed context in which National Socialism imagined itself, the subjective connotations of lieux de memoire are limiting. Instead I would argue that their creations were attempts at objective-lieux de memoire, spaces of perceived universal truth and memory but which were ultimately wholly subjective.

In other words, National Socialist architecture was envisioned to operate within a system of cultural memory imagined by its creators to be an objective fact rather than a cultural myth. As universal culture-bearers, Nazism was to provide the concepts around which time and history orbited, and thus was the guide by which the universal narrative was written rather than one story amongst many. This framing was ultimately undertaken as a means of combating fears of anticipation for the future of the regime. Architecture was an important tool in facing the future as it provided an opportunity to pre-empt both the possibility of an apocalyptic end to the regime as well as a future of eternal prosperity. Architecture used in this way was, then, a means of addressing the dualistic

${ }^{5}$ Sharon Macdonald, "Words in Stone? Agency and Identity in a Nazi Landscape," Journal of Material Culture 11, no. 1-2 (July 1, 2006): 105-26, 112. 
nature of NS rhetoric on the future as it accounted for the possibility of both the regime's terminal and eternal potential.

This sense of temporality, and specifically the use of this notion of the finality of time are what separate National Socialist architecture from others of the period. The NSDAP enlisted the help of architects and artists to put the ideals of National Socialism into tangible, physical form. Shortly after the Nazis took power, during a period of perceived improvement in European relations, German architecture and art were presented as Nazism's first foray into the international spotlight.

On the 25th of May 1937, visitors to the Exposition Internationale des Arts et des Techniques appliqués à la vie moderne were presented with a starkly contrasting and confrontational new Parisian skyline. Amidst the Gothic, Neoclassical, and Beaux-Arts buildings of Paris the recently erected structures of the World's Fair were easily recognized. The exposition, in the words of art historian James D. Herbert, "promised a comprehensive and up-to-the-minute survey of human accomplishment." ${ }^{6}$ For the four-year-old NSDAP and the ideologues of the National Socialist movement, the 1937 World's Fair was a proving ground, a space in which National Socialism could present itself to the European community on its own terms. While, collectively, the fair offered this same opportunity for the nations of the world, the German state approached its involvement in the fair as a means of exalting the cultural merits of National

\footnotetext{
${ }^{6}$ James D. Herbert, Paris 1937: Worlds on Exhibition (Cornell University Press, 1998), 3.
} 
Socialism. Germany's participation was one of the earliest instances of Nazi cultural display, and offered to the world an image of a reborn nation with a prosperous new future. This display was particularly powerful in the context of the World Fair's overall shoddy orchestration. ${ }^{7}$

For most visitors, the fair showcased wonders from some forty-four visiting nations. Those in attendance were able to walk along the Avenue de la Paix, which formed an axis from the Trocadero through the Eiffel Tower to the Champs-de-Mars. ${ }^{8}$ This boulevard represented the Sections Etrangères, where the pavilions of foreign nations were constructed. Herbert describes the Exposition experience as one where the visitor became a "Frenchman," and so the Exposition was thusly not only a market for the peddling of national products but also where the average person could experience the world through a French lens. ${ }^{9}$ For France, Herbert argues, the Exhibition was symbolic of the state in both form and function as the whole project was plagued by a poorly organized administration and lack of unified focus.

While visitors wandered through the cornucopia of sights and sounds, they would perhaps be oblivious to the failings of the Exposition's organizers. Most certainly the average Frenchman-for-a-day would have been more interested in the cultural fare on display, with the intriguing consumer innovations being

\footnotetext{
${ }^{7}$ Karen Fiss, Grand Illusion: The Third Reich, the Paris Exposition, and the Cultural Seduction of France (Chicago; London: University of Chicago Press, 2009) 49; Danilo Udovički-Selb, "Facing Hitler's Pavilion: The Uses of Modernity in the Soviet Pavilion at the 1937 Paris International Exhibition," Journal of Contemporary History 47, no. 1 (January 1, 2012): 13-47, 20.

${ }^{8}$ Udovički-Selb, 14.

${ }^{9}$ Herbert, 28-29.
} 
showcased, or with the ornamentation and nationalism of the pavilions themselves. On these fronts there was one pavilion which stood out amongst all others - centrally located along the Avenue de la Paix, within a short distance of the Eiffel Tower, and immediately across from Boris lofan's award-winning and aggressive Soviet pavilion was the exhibit of the Third German Reich. The German pavilion was a popular spot; to the average visitor it would have been an impressive structure to behold. On a scale that was simply grander than all other pavilions, and with ornamentation and materials that suggested a well-organized and prosperous new Germany, the pavilion was the National Socialist government's first sortie onto the international stage and its presence was widely recognized as being one of the highlights of the whole Exposition. ${ }^{10}$

The significance of the German pavilion for Hitler and the National Socialists was, however, not completely lost on all spectators. Considering the pavilion's imagery and placement within the Exposition site, it was obvious that there was some behind-the-scenes struggle. In one famous example, Albert Speer, the pavilion's designer, claimed that the German pavilion was actually designed to counter the aggressive advance of the Soviets' stark bulwarks. In his memoirs he wrote:

While looking over the site in Paris, I by chance stumbled into a room containing the secret sketch of the Soviet pavilion. A sculptured pair of figures thirty-three feet tall, on a high platform, were striding triumphantly toward the German pavilion. I therefore designed a cubic mass, also elevated on stout pillars, which seemed to be checking this onslaught[.] ${ }^{11}$

\footnotetext{
${ }^{10}$ Fiss, 62.

${ }^{11}$ Albert Speer, Inside the Third Reich, 1 edition (New York: Simon \& Schuster, 1997), 81.
} 
The validity of this statement is questionable, as art historian Karen Fiss notes. ${ }^{12}$ She suggests that Speer was likely given a copy of the Soviet plans by the French organizers as evident from his possession of a sketching of the Soviet pavilion featuring notations in French. This too was perhaps a response to the perceived warming of relations between France and Germany. The mild detente that featured in 1937 suggests a desire on the part of France to appeal to the Germans, as well as being an indicator of the early stages of Europe's appeasement of Germany that would define international politics in the years to follow. While France's vision of a cooperative future was fueled by the Germans' participation in the Exposition, the NSDAP's aims were distinctly less peaceful, and their presence in Paris veiled the aggressive aims of the new regime.

The German pavilion at the 1937 Exposition can be viewed as a microcosm for the aggrandizing architectural projects of National Socialism as a whole. The pavilion was symbolic beyond its skin, which presented the alluring ideal of detente to a world which had almost universally claimed large-scale conflict detestable. Its bones sung songs of conflagration and an impending steel blade ushering forth from within the German heartland. Externally the pavilion's structure hid the technological modernity of Germany behind a literal facade of ancient stone and the material construction of the pavilion suggested a readiness for war. Architectural historian Danilo Udovicki-Selb argues that the entire building was a subtle projection of Germany's military capabilities. He states,

\footnotetext{
${ }^{12}$ Fiss, 9-44; Fiss' entire first chapter deals with the strengthening of cultural relations between Germany and France.
} 
“[the pavilion's] very foundations rested on the premise of war. Reduced in size [by] one-fifth of its original scale, the pavilion still concealed 3000 tons of steel behind pink granite veneer of equal weight." Even the structure itself "was cast at the Herman Goering Werke, a military installation."13

A similar instance of this phenomena can be seen in Speer's Cathedral of Light above the Zeppelinfeld in Nuremberg, where dozens of military searchlights were used to create a great cage of light which illuminated the entire Party Rally Grounds. To outsiders this emphasized the capabilities of the new government, but within Germany there was more at work than a show of political strength. The pavilion was one of the earliest productions of its kind by the National Socialists, and under the close watch of Hitler, successive architectural works of National Socialism would be employed as tangible works of the regime's temporal-cultural obsessions.

As demonstrated by the Paris pavilion, the architectural projects of the National Socialist regime were capable of projecting messages beyond their obvious and implied purposes. This idea of didactic architecture was not invented nor even partially pioneered by Nazi architects and ideologues, however the manner in which it utilized this concept was unique. In many ways this project is the exploration of National Socialism's use of didactic architecture as it functioned within a greater cultural network of continuity and historicity - a culture of temporality. I argue that the NSDAP utilized architecture as a means of

\footnotetext{
${ }^{13}$ Udovički-Selb, 23.
} 
actualizing their desire to project tangible examples of their rhetoric of cultural continuity. The means by which NS architecture attempted to accomplish this suggests a regime which understood itself not only as existing at an identifiable "present" - that being a point in time understood to come after a perceived "past" and before and anticipated "future" - but also as a force inseparably intertwined with not only history and the historical, but the very essence of measurable time. I argue that where the World's Fair offered National Socialist architecture a proving ground for its ability to propose ideas and suggestions on the nature of its creators, later projects undertaken in this vein would expand the scope of its message beyond the local and physical towards a commentary on time itself. Architecture was to represent in steel and stone the anticipated longevity of the regime. The sites I focus on in this work are examples of this kind of architecture. Again, they are: the Reichsparteitagsgelände, Reichssportfeld, and proposed site of Welthauptstadt Germania. These envisioned projects were designed not only as physical notations of the current regime's power and ideology, but as tools to project the regime's temporal authority and perceived right to the future. The NSDAP achieved this cultural ideal though the co-option and creation of temporally sensitive cultural, rhetorical, and social structures that served to function within the Reich's larger sense of historicity and continuity. Architecture, then, provided the regime with a means to suggest its own continuity, allowing it to syphon strength in historical authority from the past, as well as provide temporal guideposts from which future iterations of the regime could look back to 
for the same historical prerogative: i.e., the creation of lieux de mémoire. This perception of time suggests that the impetus placed on history as a source of authority by the National Socialist regime rested on a specific and unique understanding of its own place within a greater historical narrative. The means by which the party utilized architecture as a tool for empire-building suggests a regime which understood itself not only as existing at a specific point within a larger temporal narrative, but also as an agent capable of manipulating the perception of this narrative itself in establishing a temporally-sensitive cultural identity that transcended the boundaries of time.

My project is intended to occupy a space I have yet to find within the existing literature on National Socialist architecture, specifically, the examination of National Socialist culture and its relationship to historical time as expressed in state building project. Where the work of scholars like Victor Klemperer and Maiken Umbach present temporality in everyday life under National Socialism, my work seeks to look at specific, grand expressions of this temporality. Situating my work is difficult as the sheer number of studies on National Socialism is staggering, and the subject matter covered is often highly politicized and rightfully sensitive. My work is concerned specifically with the NSDAP's use of art (namely, architecture) and its corresponding relationship to the regime's sense of temporality. Likewise, my project is concerned with how non-animate objects - in this case, architectural works - form part of a complex relationship of transmission and creation of culturally-inclined historical authority. 
I should note that the use of the historical as a source of authenticity is not something unique to National Socialism, nor is it, perhaps, something that can even be avoided when dealing with large-scale, societal organizations. What is unique to National Socialism is the emphasis on the inevitability of the future and the certainty of the "historical" nature of the regime's everyday actions. The emphasis on the inevitability of a National Socialist future occurred in conjunction with a parallel insistence on a selective historical record of evidence, which was used to "prove," not only a legitimacy of the current regime to rule, but a continuity of authority stretching from an imagined past into an assured future. The motif of inevitability derived from history can be seen as a predeterministic understanding of time, within which the NSDAP placed itself as the determinant focal point. This predeterministic attitude resonated throughout National Socialism's discourse of temporality.

The concept of a predetermined history in which National Socialism was the key actor is fundamental to the understanding of the National Socialist temporal mindset. Those shaping Nazi rhetoric perceived the movement as possessing a quality of historicity, and of a future destiny. The idea was that the monumental structures created in the regime's present would one day be reflected upon by National Socialists of the future as a point of historical continuity. In his memoirs, Speer described how Hitler hoped:

to transmit his time and its spirit to posterity. Ultimately, all that remained to remind men of the great epochs of history was their monumental architecture, he would philosophize. ... Periods of weakness are bound to occur in the history of nations, he argued; 
but at their lowest ebb, their architecture will speak to them of former power. ... [W] [Wen after a long spell of inertia a sense of national grandeur was born anew, the monuments of men's ancestors were the most impressive exhortations. ... Our architectural works should also speak to the conscience of a future Germany centuries from now. ${ }^{14}$

There is a sense of apocalypse in Hitler's words, however there is also a clear understanding of historical continuity. "Posterity," as Speer describes it, occurs at a point in time when people of like-mind to the National Socialists would use the regime's architecture in the same way that the NSDAP used that of Rome and Greece. In creating durable architecture that would retain its builder's imbued cultural message, National Socialism was to establish a continuity between the present and its projected future. As I will show, the act of imagining a specific future and of reifying a connection to that future suggests that the National Socialism was understood by its rhetorical benefactors to be part of a greater temporal continuum that linked past, present, and future in keeping with its ideological goals.

\footnotetext{
${ }^{14}$ Speer, Inside the Third Reich, 56.
} 


\section{Chapter 1 - The Words in Stone}

In this chapter I discuss the historiographical conceptualization of National Socialist architectural style within the existing literature, and present the twofold argument that since the literature's description of this architecture is often unnecessarily reductive - focused around cultural policies - it has often obfuscated the relevance of National Socialist notions of time as related to the regime's architectural works. To get at this, I identify the current literature and trace the development of study on National Socialist architecture, indicating where the literature's focus shifted, and suggest that changes in scholarly approach correspond to real-world pressures, including popular interest in the stakes of such research, and the availability of related primary source material. Similarly, I juxtapose the study of National Socialist culture - specifically the regime's self-identified temporality and historicity - with these architectural works in order to map moments where discussion of temporality and architecture surface within the literature. I then identify the descriptions of National Socialist style present in the literature, arguing that more stress needs to be placed on Nazi architecture as part of a larger cultural emphasis on temporality within NS rhetoric so as to move past existing reductive descriptions. Finally, I conclude by suggesting that the argument for a unique NS architecture can be found in the manner in which the regime used its architecture to foster a claim to the past and future. 
It is difficult to situate my work in the existing historiography as there are a number of studies that discuss National Socialist architecture. Because this work is specifically concerned with the NSDAP's use of architecture as an expression of the regime's temporality, it lies at the intersection of three distinct literatures. Furthermore, it examines the subject from an historiographical, cultural, and architectural approach, incorporating theoretical insights from several disciplines. It draws not only from the historical discipline, but also from architecture, cultural studies, art history, and theology.

The literature on National Socialist architecture can be divided into three broad periods of study, between which shifts in approach, available source material, and consensus swayed the dominant narrative. These periods are: the immediate post-war, which relied heavily on sporadic and unreliable first-hand information; the period of contextualization, when NS art and architecture became the focus of studies interested in exploring the NSDAP's cultural and creative works; and the period of increased access to documentation following the collapse of the Soviet Union and the opening of previously inaccessible archives in the East. Much of the earliest writing on NS architecture came from official channels in the regime or from those closely associated with high-ranking party officials, and in-particular, the cadre of architects whose ran in Hitler's inner circle. Notable members of this group include Albert Speer, Paul Troost, and Gerdy Troost. 
Gerdy Troost, the wife of architect Paul Troost and personal friend to Hitler, took over her husband's architectural firm after his death in 1934. We can see the importance of architecture as expressed in her comments at the time. She continued to work for the NSDAP - specifically Hitler - as one of his "state architects." In 1938 she published Das Bauen im Neuen Reich ("Building the New Reich"), in which she describes the changing face of architecture under National Socialism. This text, like many published during the period, was through and through, pro-NS propaganda, written by a member of the party (Troost had joined in 1932) exalting the works of the state. ${ }^{15}$ Nevertheless, it stands as an interesting introduction to NS architectural historiography. Troost's book was published in German, for a German readership, however the party had international audiences to address as well. In November of 1940 Dr. Matthias Schmitz published A Nation Builds: Contemporary German Architecture. The nearly 140-page book was printed in English by the German Library of Information in New York, an institution established and funded by the German consulate with the guiding principle of promoting and explaining National Socialism in America. Schmitz's book is one of the earliest English-language texts to discuss the NSDAP's architectural program and, as-such, can be considered, along with Troost's work, part of the foundational works of NS architectural historiography. A Nation Builds is unabashedly propagandistic and was written in order to better serve the NSDAP's presence abroad. The primary

\footnotetext{
${ }^{15}$ Other texts, like the official post-games pamphlet published for the 1936 Olympics in Berlin discuss the role of architecture in shaping the state's vision.
} 
aim of architectural readers published under National Socialism was to reinforce existing party narratives and present an appealing image of the NSDAP's new state. These works provide insight into the party's public rhetoric in addition to the architecture itself. Arguably, there is a fifth period, that of the NSDAP's tenure in power. This era, however, contains only a few samples of study as many, if not most, of the architectural projects of interest had yet to be completed, and most of the discussion of the regime's architecture was put out by the party and its affiliates as a means of propagandizing National Socialist artistic value.

In the post war period there was a drastic shift in how NS architecture was studied. With the fall of the regime, so went the enthusiastically nationalist exaltations of pride in the Reich's new buildings. After the initial chaos of war's end had settled down, and access to the remaining documentation became more - albeit not totally - open, a new generation of texts started to emerge. Academics from outside Germany, particularly in the United States, wrote on the subject, fascinated by the grandeur and totalizing nature of NS architecture as a product of the regime. This period, from 1966 to $1981,{ }^{16}$ marked a watershed of outside research on NS architecture. This is no doubt related to the imprisonment and death of Albert Speer, who is considered to be one of the most important figure in the study of NS architecture ${ }^{17}$. Speer, who was released from Spandau prison in

\footnotetext{
16 The period between 1945 and 1966 saw little in the way of manuscript production on the topic of NS architecture, with the first major texts being written in the mid-1960s.

17 The field of NS architecture appears to hinge quite significantly on Albert Speer's word, with numerous works relying on Speer as a source to some degree. Examples include (but are not limited to): Adam's Art of the Third Reich, Fiss's Grand Illusion, Hochman's Architects of Fortune, James's German Architecture for a Mass Audience, Macdonald's Difficult Heritage, Michaud and
} 
1966, was the foremost source of information on the NSDAP's architectural program in the post-war world. With primary documentation difficult to come by, either because of its destruction during the final days of the Reich, or because of the inaccessibility of now Soviet-controlled archives, Speer's personal accounts became the main focus of academic study which sought to explore not only architecture, but through it Hitler's personal life and the party's internal machinations. Speer's work is often cited in texts that discuss NS architecture and the party.

An example of Speer's influence is Barbara Miller Lane's book Architecture and Politics in Germany, 1918-1945, which was published in 1968. In it, Lane discusses the creation of NS architecture in terms of its continuation of a stylistic legacy founded in the 1920 s, which itself is a continuation of extant European and international trends. ${ }^{18}$ Lane's text, like many published in this period, is guided by the idea that NS architecture lacked a unique style ${ }^{19}$ and was, instead, the culmination of either a long-process of stylistic architectural progression or an amalgamation of other existing styles, lacking in its own authenticity. ${ }^{20}$ This attitude can be traced back to a note made by Speer during

Lloyd's The Cult of Art in Nazi Germany, Scobie's Hitler's State Architecture; the Impact of Classical Antiquity, Taylor and Wil's, The Nazification of Art, and Taylor's The Word in Stone. ${ }^{18}$ Barbara Miller Lane, Architecture and Politics in Germany, 1918-1945 (Cambridge, Mass: Harvard University Press, 1968), Lane, 190-192.

19 The debate over unity of style is also a reoccurring issue in discussions of social realism as well as National Socialist architecture, suggesting that the problem of identifying and accepting apparently repurposed styles is an ongoing one.

20 Ibid., 185 ; Peter Adam, Art of the Third Reich (New York: H.N Abrams, 1992), 11-15 ; Alexander Scobie, Hitler's State Architecture; the Impact of Classical Antiquity, Monographs on the Fine Arts 45 (University Park: Pennsylvania State U, 1990) 14-22; Robert R. Taylor, The 
his time in Spandau. With the aid of biographer and historian Joachim Fest, Speer was able to turn his notes into the autobiographical text Erinnerungen ("Recollections"), which was published in 1969 and Spandauer Tagebücher (“Spandau Diaries"), which appeared in 1975. These books were subsequently translated into English and released as Inside the Third Reich and Spandau: The Secret Diaries in 1970 and 1976 respectively. Here, Speer discusses the existence of, what he calls, a "Fuehrer's style:"

There was no "Fuehrer's style," for all that the party press expatiated on this subject. What was branded as the official architecture of the Reich was only the neoclassicism transmitted by Troost; it was multiplied, altered, exaggerated, and sometimes distorted to the point of ludicrousness. Hitler appreciated the permanent qualities of the classical style all the more because he thought he had found certain points of relationship between the Dorians and his own Germanic world. Nevertheless, it would be a mistake to try to look within Hitler's mentality for some ideologically based architectural style. That would not have been in keeping with his pragmatic way of thinking. ${ }^{21}$

This argument for the NSDAP's stylistic borrowing of past iconographies permeates the literature of this period, the common narrative being that the NSDAP adopted neo-classicism (the so-called "Doric") and modernism in-order to create their preferred aesthetic. Lane's text relies almost exclusively on the archives of Walter Gropius - the founder of the Bauhaus - and thus plays into existing narratives of NS hostilities against that artistic institution. ${ }^{22}$

Word in Stone: The Role of Architecture in the National Socialist Ideology (Berkeley: University of California Press, 1974), 38-39, 78-89; and to a lesser extent, Fiss, 62-65.

${ }^{21}$ Speer, Inside the Third Reich, 42-43.

22 Elaine S. Hochman, Architects of Fortune: Mies van Der Rohe and the Third Reich, 1st ed (New York: Weidenfeld \& Nicolson, 1989), 3-9; Scobie, 13; Taylor, 6-7, 38, 44, 54. 
In 1974 historian Robert Taylor published The Word in Stone: the role of architecture in the National Socialist ideology. In it, he discusses the then-current literature and attempts to suggest, again, that there is no such thing as a National Socialist style. ${ }^{23}$ Taylor's work may be seen as a successor to that of Lane; he identifies many of the same trends but is attempting to advance his own theories on the ineffectiveness of architectural affect under the NSDAP. I use the term "attempting" here because Taylor's work stands out as being difficult to follow and often relies on contradictory information that he does not address.

Additionally, he is noted as having misused translated terms to frame two of his main arguments. ${ }^{24}$ Taylor is important, however, in the context of the literature's development. Written near the end of Speer's predominance, Taylor does not fall into the trap of unilaterally arguing that architects working with the NSDAP must be inferior to those that fled. This "the good leave, the bad stay" motif is common in early studies of architecture in Germany, particularly those that reflect upon the Bauhaus and its disciples. ${ }^{25}$ The danger in this approach is that it furthers the narrative of artistic objectivity, within which those that collaborated with the regime are considered inferior artistically solely on moralistic arguments, which unhelpfully dismisses the arguments of the subjectivity of art. Ultimately, as we

\footnotetext{
${ }^{23}$ Ibid., 78-82.

${ }^{24}$ Ronald Wiedenhoeft, review of Review of The Word in Stone: The Role of Architecture in the National Socialist Ideology, by Robert R. Taylor, Journal of the Society of Architectural Historians 34, no. 2 (1975): 157-59, 157.

${ }^{25}$ Hochman, 110; Kathleen James, German Architecture for a Mass Audience (London; New York: Routledge, 2000), 69; Brandon Taylor and Wilfried van der Will, eds., The Nazification of Art: Art, Design, Music, Architecture, and Film in the Third Reich, 1st ed (Winchester, Hampshire: Winchester Press, Winchester School of Art, 1990), 110-112.
} 
will see, the attribution of "good" and "bad" architect were largely guided by the studies of the period in subsequent years, wherein the rise of national Socialism and its profound impact on those producing during the period framed discussions of artistic merit.

There is a reoccurring theme within the literature on German architecture of the early 20th century, which defines the quality of the architects by their ability to escape the grasp of National Socialism. Those who fled Germany, particularly to the United States, are revered as intellectual pioneers at the vanguard of architectural styles. Those who did not flee, who continued to work in Germany and who cooperated with the NSDAP's artistic and cultural policies were relegated to the realm of uncreative hacks, lacking their own vision. ${ }^{26}$ This argument is particularly visible in discussions of the Bauhaus; the closure of which in 1933 was considered the end of modern design in Germany. In his essay "Modernism and Archaism in Design in the Third Reich," John Heskett discusses the Bauhaus as a common point of change within German artistic rhetoric. He writes, "A consequence of [the] failure to consider the full breadth of design in Weimar Germany has been the depiction of the Third Reich simply in terms of a negation of the avant-garde tendencies optimized in the Bauhaus."27 Heskett notes that design historians lag behind the discipline when coming to terms with the subjectivity of form and design under National Socialism, citing

${ }^{26}$ Adam, 65, 211; Kathleen James, Erich Mendelsohn and the Architecture of German Modernism, Modern Architecture and Cultural Identity (Cambridge, U.K. ; New York, NY, USA: Cambridge University Press, 1997),107, 232; Wiedenhoeft, 157.

27 Taylor and Will, The Nazification of Art. 110. 
one exhibit staged in Munich in 1977 which asked of its audience, "were there in fact works of meaning in the Germany of the regime that artistically survived this period?" This question is indicative of the shifting impetus of legitimacy placed on art and architecture during the NSDAP period. This specific exhibit's answer rang familiar with earlier studies, identifying artists who resisted the regime as the sole arbiters of style in a period otherwise devoid of creativity. ${ }^{28}$

The 1970s saw a shift in the qualitative designation of "good and bad" architecture, of the distinction between "artist and hack" in what amounted to a move to allow a greater acceptance of the artistic value of works created under National Socialism. Taylor's book is one of the earliest examples of this shift, and his work is ultimately caught between the first wave of research - notably due to his reliance on arguments of Speer's character, which paint the architect as a naive patriot ${ }^{29}$ - and the period of revision that occurred in the 1970 s and 1980 s. The Word in Stone represents a work of transition, one which still emphasizes the observed place of architecture within the Third Reich. Later studies would expand on this motif and further explore the cultural implications of architecture under National Socialism.

Questions of the validity of Speer's testimony and the legitimacy of his claims of non-involvement in the regime's war crimes shaped the literature's focus during Speer's final years. In 1981 the architect and former Minister of Armaments died. Notably, while the architectural projects of National Socialism

\footnotetext{
${ }^{28}$ Ibid., 111.

${ }^{29}$ Taylor, 69-71.
} 
and the Soviet Union were, and still are, often compared as parallel examples of "totalitarian" architecture, histories of NS architecture, particularly those which relied heavily on Albert Speer, were largely overlooked in the Historikerstreit or Historians Debate of the late 1980s. While Speer's involvement, and that of public works under the NSDAP in general, escaped early discussions of participation in NS crimes, later studies would reveal the duplicity of Speer's initial testimony at the Nuremberg Trials. After the collapse of the Soviet Union, and the eventual opening of the Soviet archives, scholars gained access to a wealth of wartime and prewar NSDAP documentation that had previously been secured behind the Iron curtain, and within Nazi Germany before that. The influx of newly available material seemingly reinvigorated scholarly discussion on the use of architecture under National Socialism, within which there was a great deal of interest in how the architectural projects of the Third Reich fit into the greater history of the regime's crimes, while stirring up a deeper discussion of the sociocultural aspects of National Socialism. ${ }^{30}$

\footnotetext{
${ }^{30}$ The Historikerstreit ("historians' debate") was an intellectual dispute between historians of National Socialism who debated the validity of comparing the crimes of the NSDAP with those of the Soviet Union. Those on the left argued against meaningful comparison, generally arguing for The uniqueness - and specifically the "evil" - of NS crimes, while right-wing proponents of comparison argued that similar atrocities had been carried out in different locals by different regimes before and after the Third Reich. The idea that the crimes of the Third Reich were uniquely evil is derived from a similarly polarizing debate, that of the Sonderweg ("special path"), which argues that Germany experienced a process of democratization unique amongst the powers of Europe. This uniquely German experience, Sonderweg posits, is one which ultimately fostered conditions favourable for the rise of National Socialism. The Historikerstreit was predominantly a focus for historians during the later 1980s, while the Sonderweg theory has been a recurring explanation for the rise of Nazism since the Second World War. Both the Historikerstreit and Sonderweg discussions were reignited during the 1990s and early 2000s as historians began the process of exploring the unrestricted Soviet Archives.
} 
In the 1990 s and 2000 s there was a shift away from examining the NSDAP's architecture as solely structure and design, towards a greater emphasis on contextualizing these projects within National Socialism as a cultural and political movement. This shift included a greater focus on recontextualizing architecture as a public works program functioning as part of the National Socialist Party's political machine. Art historian Paul Jaskot's book The Architecture of Oppression examines the use of forced labour in the creation of the Third Reich's monumental building plans, while Adam Tooze's The Wages of Destruction sheds light on the dubious reliability of Speer's personal records and the logistics of how his ministries operated. My own interests in National Socialist architecture fall in-line with those scholars who look to interrogate NS architecture as a cultural phenomenon. Examples of this focus can be found in the works of Karen Fiss, Kathleen James, Joshua Hagen, and Sharon Macdonald, whose projects range from Fiss' discussion on the 1937 World's Fair, to Hagen's description on the remodeling of an ancient town's architecture to better suit NS political needs. The post-Soviet era witnessed the synthesis of both cultural and architectural histories of National Socialism.

It is important to remember that the NSDAP was a cultural entity as well as a political apparatus. Historians have discussed the cultural implications of National Socialism in more depth since the 1970s, when the discipline as a whole moved away from more epistemological studies. In 1971 Richard Grunberger published A Social History of the Third Reich, in which he explored the social 
history of the NSDAP and life under NS rule. Grunberger's work was, however, far from an exhaustive survey. More contemporary work, like Lisa Pine's Hitler's National Community, built on this legacy of study to examine the means by which the NSDAP imagined its own culture. Pine's book presents National Socialism as an identity, and focuses on the party's use of Volksgemeinschaft ${ }^{31}$ as a gauge of othering. ${ }^{32}$ Further studies have focused on the use of culture as a weapon against those othered by the regime. Infamously, Daniel Goldhagen's book Hitler's Willing Executioners depicts National Socialist culture as being the continuation of existing social-cultural trends in Germany, specifically those that promote an acceptance of violent anti-Semitism. Goldhagen's work falls along with other continuation-oriented histories as part of the largely discredited Sonderweg argument.

Since the reunification of Germany historians have worked on tackling the issue of cultural memory within the long-divided state, including how the reunited Germany dealt with - and still deals with - its National Socialist past. Within these discussions there is an exploration of the NSDAP's architecture, as it represents a tangible link to the past, and an often uncomfortable reminder of the nation's history. In more recent years there have been works written discussing the use of architecture in the context of cultural meaning. Sharon Macdonald's Difficult Heritage is one such example. In it, Macdonald discusses the continued NS

\footnotetext{
${ }^{31}$ Pine translates this explicitly as "National Community."

32 Lisa Pine, Hitler's "National Community": Society and Culture in Nazi Germany (London: Hodder Arnold, 2007), 2.
} 
presence in Nuremberg, describing the ramifications of Nazi architecture's presence in a city that is no longer bound by the culture that created it. Macdonald explores the issues that arise from the presence of these culturaltemporal works architecture in a starkly contrasting and vastly different cultural environment than that in which they were designed to function. Largely this field is concerned with understanding how NS architecture fits into the contemporary memoryscape, with the goal being to better understand and come to terms with as Macdonald puts it - Germany's "difficult heritage." As I have noted, my work seeks to investigate the importance of culture and architecture in the context of the regime's own imperatives rather than stress how they relate to modern audiences. I am more interested specifically in how the regime understood itself as an historic entity. ${ }^{33}$ Macdonald's 2006 article "Words in Stone?" comes closest to mirroring my own interests, however in her article she is largely still focused on these structures as they fit into a modern context, and their agency as historical actors within a broader framework of memory and trauma. Macdonald does address the NSDAP's own historicity and how they sought to use architecture as a means of "speaking" to the future. ${ }^{34}$ The question of National Socialism's historicity has been discussed within the literature, however only in recent years

\footnotetext{
${ }^{33}$ Throughout this chapter, and indeed through most of my project, I use the term "regime," "party," and "NSDAP" interchangeably. I do this as a means of describing National Socialism as a fluid entity, however I should note that while I discuss National Socialism as an umbrella term, I do so in the context of my current discussion of historicity and culture, and with the understanding that the party was comprised of individuals whose worldviews did not necessarily align with each other or even perhaps allow for a definitive, usable, and all-encompassing average of opinions that could be ascribed as "National Socialist." I address the specific contributors to the "National Socialist culture" in more depth in chapter 2.

${ }^{34}$ Macdonald, "Words in Stone?" 105.
} 
has this discussion begun to incorporate tangible examples that emphasize the regime's predilections for culturally and temporally-inclined architecture, and even then, descriptions of this crossover of ideas are often discussed in a reductive tone..$^{35}$

The literature describes NS architecture as an amalgam of different styles, often attributing NS style to a blending of the so-called "Doric" favoured by Hitler, the Volkisch architecture championed by Rosenberg, ${ }^{36}$ or the modernism of Speer. Where this argument cites the use of existing stylistic practices and the adoption of artistic trends as evidence for the banality of NS architecture, I argue that it is the act of adoption and of sampling that suggests a uniqueness of approach, as well as the proposed intent of the work that demands a reassessment of current descriptions, which are inherently reductive in their examination of a National Socialist style.

As I previously mentioned, it is likely that the impetus to reduce NS style to its base components stems from comments made by the former Generalbauinspektor für die Reichshauptstadt ${ }^{37}$ as well as a long-held hesitation by the academy and the arts to treat creative works produced under National Socialism as cultural production in their own right. If we accept that NS style is a

\footnotetext{
${ }^{35}$ Adam, 211; Eric Ehrenreich, The Nazi Ancestral Proof: Genealogy, Racial Science, Andthe Final Solution (Bloomington: Indiana University Press, 2007), xii; Scobie, 93; Albert Speer, Albert Speer: architecture, 1932-1942 (Bruxelles: Archives d'architecture moderne, 1985), 214; Taylor, 108-110.

36 Taylor and Will, 83-87.

${ }^{37}$ German "General Building Inspector for the Reich Capital," a position that made Speer the defacto Architect of the Third Reich.
} 
culmination of existing trends, what makes that instance of artistic borrowing different from other examples? I argue that the monumental architectural projects envisioned under National Socialism constitute a unique instance of architectural style as their use of existing styles was done so within the context of a greater cultural program of historicity, and within a culturally-inclined framework of temporality that sought to create tangible embodiments of the regime's rhetorical understanding of its own place in time.

In a speech in Berlin on November 27th, 1937, Hitler - discussing the plans for remodeling Berlin - said, "The magnitude of these works is not measured by the need of 1938,1939 , or $1940 \ldots$ our task is to give the people who have existed for a thousand years, with their millennial past of history and civilization ... a millennial city [Berlin] for the limitless future which lies before them." ${ }^{38}$ Unlike many of its contemporary states, the Third Reich employed architecture not only as a means of promoting state politics, but as part of a grander strategy of temporal security, one which was designed to act in tandem with other cultural programs, ensuring the regime's everlasting survival into the annals of history. In the next chapter, I will expand on this theme of NS temporal architecture in order to demonstrate the pervasiveness of temporality within National Socialist rhetoric and culture.

${ }^{38}$ Frankfurter Zeitung, November 29, 1937 (as cited in Adam.) 


\section{Chapter 2 - Terminally Eternal}

In this chapter I examine the historicity of National Socialist culture. First, I present the ideals of past and future within NS rhetoric, emphasizing the importance placed by the NSDAP on "historical evidence" and the mythicality of a NS future. I argue that National Socialism had a unique understanding of its own historicity, one which was derived from the philosophy of its leadership and imposed on its subjects by the enforcement of a temporally-sensitive cultural ideology specifically expressed through architecture. I then delve deeper into what the party considered to be appropriate "evidence" for its temporal mythology, exploring the methods used by the regime to create the myth of an idealized National Socialist past and future. This includes, but is not limited to: the regime's archeological focus, the co-option of existing temporally-sensitive cultural entities, the infiltration of temporality into everyday speech, the rhetoric of party leaders and ideologues, and the use of state-sponsored architectural projects. These architectural projects represent the physical manifestation of National Socialism's temporally-inclined worldview, one in which conforming evidence was highly regarded, and thus became one in which the creation of self-fulfilling historical proof was a common act.

The Third Reich was obsessed with history and the place that the regime might occupy within the greater scope of historical remembrance. This preoccupation with the historic was not solely emphatic of the regime's 
admiration of the past, but also included a fascination with the putative future and what role National Socialism would play in it. The regime's understanding of itself as historical can be reiterated in terms of historicity. While the rhetoric of the NSDAP relied heavily on myth and imaginative interpretations of the past, specific members understood themselves, and their party, to exist at a point that would - in their optimistic understanding of events - eventually become the past of a future iteration of the regime. While I have described National Socialism as a whole entity, it would be incorrect to label it as having a unified cultural vision. In this chapter I will discuss specific members of the regime and how their individual worldviews contributed to shaping the regime's applied historicity and temporal outlook. In more overarching, rhetorical terms, the NSDAP perceived itself as being part of a long and continuing temporal existence of greatness, one which extended from the distant past to the distant future. ${ }^{39}$ Within party dogma and ideology both the past and future represented important spaces of cultural divination for the regime's post-Weimar, unstable beginnings.

The rhetoric of the NSDAP exuded an intense fascination with the past and how it was remembered, and thus represented a powerful source of cultural authority for the fledgling government. NS ideologues made frequent reference to the importance of the past in the continuation of the party, often extolling connections to ancient institutions and empires in an attempt to assert historical

\footnotetext{
${ }^{39}$ Victor Klemperer and Martin Brady, The Language of the Third Reich: LTI - Lingua Tertii Imperii: A Philologist's Notebook (London; New York: Continuum, 2002), 45.
} 
criteria for its current rule. ${ }^{40}$ The nomenclature of the "Third Reich" itself was an indicator of National Socialism's historical inclinations: hearkening back to previous Germanic kingdoms, the party used this descriptor to bolster their own right to exist; the third - and purportedly final - incarnation of a grand Germanic empire whose lineage stretched back to the time of the Holy Roman Empire and whose historic precedent and connection further backed the regime's claim to authority. In the many speeches and internal discussions on the importance of cultural authority under National Socialism there was a generalized conflation of history and the past - a clash between what was imagined and what had occurred. There was, amongst the ideologues and policy-makers, a highly contradictory understanding of the past as both rooted in a reliance on objective, fact-based evidence, and the product of a subjective interpretation of the historical "facts." 41 The past, then, was a space in which historical authority could be extracted and processed as-needed through the party's ideological filters, providing the cultural capital needed to reinforce the regime's current and future legitimacy. Ultimately, this way of thinking gave rise to the privileging of the remembered past within popular discourse $\mathrm{e}^{42}$ and official propaganda. ${ }^{43}$

\footnotetext{
${ }^{40}$ Adolf Hitler and Abraham Foxman, Mein Kampf, trans. Ralph Manheim, 20th edition (Boston: Houghton Mifflin, 1999), 14-15, 205-206; Chandler; Pine; Speer, Inside the Third Reich, 56, 86, 94-95, 315; Joseph Tenenbaum, Race and Reich; the Story of an Epoch (New York: Twayne Publishers, 1956), 29.

${ }^{41}$ Bettina Arnold's article "'Arierdämmerung': Race and Archaeology in Nazi Germany" discusses the fabrication of "factual" evidence by the regime for ideological purposes.

42 Klemperer and Brady, 221.

${ }^{43}$ Randall L. Bytwerk, Bending Spines: The Propagandas of Nazi Germany and the German Democratic Republic (East Lansing, Mich: Michigan State University Press, 2004), 25.
} 
National Socialism was - as a movement - an historical entity, one whose existence not only hinged on the historical past, but on whose actions history itself pivoted. ${ }^{44}$ Rhetorically, National Socialism understood its own time not only in terms of past and future, but in a more totalizing way, in terms of history. That is to say, the present of the 1930 s and 40 s was not only the present, but was conceptualized as the eventual history (and past) for future National Socialists. In this way, the future and present were understood in terms of their relation to history - to the recorded and promoted understanding of past events - with the future knowing the present as the past. The past was a privileged temporal space from which authority was extracted, not only by the current regime, but by its future iterations. I should note that the use of history as a source of authenticity is not something that is unique to National Socialism, nor is it, perhaps, something that can even be avoided when dealing with large-scale, societal organizations. What is unique to National Socialism is the emphasis on the inevitability of the future and the certainty of the "historical" nature of the regime's everyday actions. The emphasis on the inevitability of a National Socialist future occurred in conjunction with a parallel insistence on a selective historical record of evidence, which was used to "prove" not only a legitimacy of the current regime to rule, but a continuity of authority stretching from an imagined past into an assured future. The motif of inevitability derived from history can be seen as an almost pre-

\footnotetext{
${ }^{44}$ Hitler and Foxman, 3, 29 ; Speer, Inside the Third Reich, 56; Eric H. Vieler, The Ideological Roots of German National Socialism, McGill European Studies, vol. 2 (New York: P. Lang, 1999), 31.
} 
determinist understanding of time, within which the NSDAP placed itself as the determinant focal point, around which all of history was shaped. This predeterministic attitude resonated throughout National Socialism's discourse of temporality and is one of the factors that distinguishes National Socialist historicity.

While the National Socialist's perception of history and time evoked a grand and spiritual progenitor, they did not divine their temporal philosophies. Like most of the internal politics of the party, the official ideological standpoint on history and the historical were part of a larger and much more conflated debate on the direction of the party's cultural aims' one derived from the personal beliefs of various Nazi officials and members of the High Command. The assorted ideological aims of the NSDAP's upper echelons fed into, and largely reinforced the myth of the "historic" National Socialism. There were several predominant figures in the party whose personal beliefs and/or political work furthered the narrative of historic, evidential proof, and of NS historicity. There were, or course, the party ideologues, persons whose names are synonymous with National Socialism: Hitler, Goebbels, Himmler, Darré, Rosenberg, and Bormann. There were also the lesser-known members - Albert Speer, Robert Ley, and Baldur von Schirach - whose work within the party contributed a further articulation of the "historic" myth. Between these figures there were contesting individual worldviews vying for prominence within the party's greater cultural expression. This contention was particularly notable when it came to the NSDAP's official 
stance on heritage and ancestry. Within the party there was a divide over what historical motif would best represent the National Socialist movement: the idyllic medieval Volk, or the legendary Dorians - both sides had their champions and detractors, with Rosenberg being a notable opponent of all things modern. While this debate was primarily had within the context of state-sponsored artistic expression - in-particular architecture - it did reflect a greater contest for power within the regime's upper echelons. ${ }^{45}$ The various personal interests of the NSDAP's leadership manifest themselves across the spectrum of National Socialist cultural endeavours, however the common thread of a desire for, and reliance on tangible, evidentiary proof united the regime's far-flung historicalcultural projects.

What constituted "evidence" of a particular historic belief varied wildly from project to project, however there was a general consensus that physical proof that could function alongside existing philosophies was of highest value. Tangible evidence played into the NSDAP's existing practise of didactic philosophy. Myths and history overlapped and gained recognition as authentic through the use of evidential support that came in the form of anthropological studies, ${ }^{46}$ archeological evidence, ${ }^{47}$ the rebinding of common parlance, the appropriation and repurposing of existing cultural beliefs, the fabrication of rhetoricallysupportive public works, or even by the direct dictation of the regime itself.

\footnotetext{
${ }^{45}$ Speer, Inside the Third Reich, 87.

${ }^{46}$ Ehrenreich, 124-125.

47 Bettina Arnold, “' Arierdämmerung ': Race and Archaeology in Nazi Germany," World Archaeology 38, no. 1 (March 2006): 8-31, 18.
} 
Notably the creation of evidence, the translation of myth into fact, was not perceived as a reliance on falsehoods - rather, the concept of mythus, as found in Rosenberg's work, is meant to evoke, as Chandler describes, "something which is true in a profounder way than science or common sense... a view of life and nature that is accepted on faith and inspires social action." 48 The truth of National Socialist ideology and rhetoric was not in question, but rather was only in need of evidence to reinforce the existing truth, to articulate National Socialism's quasi-teleological historical outlook.

National Socialism as a social organization was built upon the idea of a national community. ${ }^{49}$ George Mosse describes the National Socialist movement as relying on presumed traditions to sooth the chaos of their present. This hearkening back to an idealized past helped frame a proposed reimagining of Germanic morality and culture under National Socialism, however in actuality, the regime's emphasis on traditional values was largely not rooted in the periods that were attributed, but was instead a reflection of a nineteenth century worldview. ${ }^{50}$ Despite this glaring contradiction, the party's orators and authors decreed the need to embrace the Volkisch unity of the people, promoting the understanding that good National Socialists, good Germans, were an unmistakable group sharing a distinct cultural and racial heritage. The community, or

\footnotetext{
${ }^{48}$ Chandler, 6.

${ }^{49}$ Pine, 3-4.

${ }^{50}$ George Lachmann Mosse, Nazi Culture: Intellectual, Cultural and Social Life in the Third Reich (Univ of Wisconsin Press, 2003), xxvi.
} 
Volksgemeinschaft, ${ }^{51}$ was utilized in party rhetoric to instill a sense of ancestral commonality. The mythos propagated by the writings of such party members as Rosenberg and Darré proposed the community as identifiable by common ancestry and emphasized the relationship between those who made up the community, and the land upon which they lived - ideologically these two elements were inseparable. This duality of people and place was described as the ideology of Blut und Boden, or "Blood and Soil," and is notably one of the foundational tenets of National Socialist philosophy. The concept of Blut und Boden was popularized by Darré, primarily during his tenure as head of the Reich Ministry of Food and Agriculture, but was inherently tied in with existing racial theories that permeated National Socialist circles. The rhetoric behind Blut und Boden paralleled other "community"-building philosophies present under National Socialism in its shared emphasis on the past and on a perceivable history, in particular a biological and purportedly scientifically-defendable genealogical lineage. As a fundamental pillar of National Socialist belief, personal identity became attached to membership in the Volksgemeinschaft. The livelihood of the average person was thus intrinsically associated to provable familial history in a complicated network of racial and cultural policies that dictated status within the new regime.

Notoriously, racial identity became a prerequisite for job security and career advancement, NS party membership was based on racial purity and

\footnotetext{
51 Pine's translation
} 
political involvement was therefore restricted solely to those who fell into the desirable branches of the regime's racial hierarchy. There are many available studies of the NSDAP's racial program and their application of pseudo-scientific methods of identifying racial purity, however what we can take away from this plethora of material is the impetus on establishing a direct lineage to the past. The "blood" and "soil" of Blut und Boden represent not only the contemporary political and social aims of the regime - namely aggressive expansionist and racist proclivities - but also an overlying enthrallment with continuity, with drawing connections through time between the regime and its perceived predecessors. Within this philosophy was the myth of a Nordic peoples who were, in the words of Arnold, "simultaneously the most superior and the most vulnerable of the world's race,"52 desperately waging a war for continued racial existence. Mosse describes the Aryans of National Socialism as being, as "'genuine' in their basic emotions as nature herself." Noting that within this worldview it was the leadership's role to, "awaken these emotions, to bring to the surface the belief in race and blood" in order to continue the struggle for survival. ${ }^{53}$ The myth of a great but downtrodden civilization resonated well with National Socialists and Germans at large who still remembered the end of the previous war with chagrin. Volksgemeinschaft presented an ideally remembered past that neatly satisfied contemporary desires for a cultural heritage of strength and majesty rather than defeat and humiliation. Additionally, it incorporated a dynamic of inclusion and

\footnotetext{
${ }^{52}$ Arnold, 9.

${ }^{53}$ Mosse, 3.
} 
exclusion, which allowed for those othered by the regime to bear the blame for society's past ills. Within this narrative, the past was a place of legend from which contemporary observers could draw strength, but the motif of a people on the rise suggested that strength lay, not only in the past, but the future as well.

From the broader definition of National Socialist culture, with its focus on race and the dichotomy of internal and external community members, there is an undercurrent of historicity and an emphasis on the historical and the eventual. The rhetoric of National Socialism is one of past and future, or history and destiny. There is an emphasis on the relationship between the state's present, its past, and its future beyond their sequence of progression. In one particular issue of the Zeitschriften-Dienst - a weekly newsletter designed to aid magazine editors adhere to the regime's doctrinal policies - the making of the historical is promoted by the state. The October 31st, 1941 issue of Zeitschriften-Dienst dictates discussion on the inevitable fall of the Soviet Union, and specifies that such discussion should emphasize the racial and cultural threat that the USSR represents, in particular, its historical parallels to the "Huns and the Mongols." Interesting the article, while clearly playing on rhetoric of Soviet orientalism, cautions against using the term "Asiatic" in any attacks on the USSR for fear of insulting potential Asian cultures. The issue provides explicit historical examples to emphasize and to avoid, including instructions to "not say that the Persian kings' attacks on Greece were a danger to European culture, since the Persians were an advanced Nordic people" and a list of historical situation which offered 
useful propagandist reinforcement. ${ }^{54}$ Notable here is the way in which the regime cherry-picked what it considered historically relevant. There are additional remarks cautioning against denoting Turkey as non-Aryan, for fear that it would upset potential national allies. Ultimately this information was not intended for public consumption; Instead, the regime's audiences would receive a synthesized lesson in cultural history, informed by the "historical" qualities of the regime and its deeds within the larger narrative of projected National Socialist continuity.

The Blut und Boden narrative in particular relied on a generalized and pseudo-scientific foundation which sought to reinforce existing narratives through substantiating propaganda and the acquisition of tangible proof. In addition to the selectivity of public access to knowledge and state-mandated news, the party expended a great deal of effort in the pursuit of evidence that conformed with its own rhetoric. When confronted with contradictory revelations, there was little hesitation within the party to dismiss findings in favour of corroborating proof. On this last point Rosenberg spoke explicitly. Chandler describes Rosenberg's "adherence to historical views which [Rosenberg] admits are incapable of scientific proof." ${ }^{55}$ Rosenberg's ideological dismissal of "facts" allowed the regime an out for when physical evidence could not be obtained. The result of the ideologically-imposed meaning of evidence, and the resulting subjectivity of what

\footnotetext{
54 "Decisive Battles — Battles of Annihilation." Zeitschriften-Dienst, October 31, 1941.

${ }^{55}$ Chandler, 68.
} 
was presented as objective historical truth, was a regime that used its own historical interpretation as a tool to rewrite not only "history," but the past as well.

Evidence for how influential the adherence to projected cultural histories was under National Socialism can be found in the co-option of academic archeological and anthropological endeavours by party rhetoricians. Under the authority of the ministry of culture and surveillance colloquially known as the Amt Rosenberg (Rosenberg Office), the Reichsbund für Deutsche Vorgeschichte (Reich Society for German Prehistory) produced archeological work that reinforced the regime's cultural rhetoric. ${ }^{56}$ Archeological studies under National Socialism relied heavily on the use of Volkskunde (Folklore) in the exploration of cultural heritage, however the NSDAP were not the originators of this idea. Archeology had been applied to further nationalist aims since the $1800 \mathrm{~s} .{ }^{57}$ Under National Socialism, the use of the archeological sciences expanded to not only provide desired answers for the past, but to help lay the foundation of an explicitly future-oriented cultural policy. Arnold writes,

Prehistoric archaeology [was] conscripted into identifying the cradle of the Aryan cultural progenitors in northern and central Europe, characterized by an uncompromised, pure Germanness that would provide the template and the basis for the rebirth of the German race through a return to its origins. ${ }^{58}$

\footnotetext{
${ }^{56}$ There are currently several monographs examining the subjugation of academia under National Socialism. For further reading on this subject see Lixfeld's Folklore and Fascism, and Dow and Lixfeld's The Nazification of an Academic Discipline.

${ }^{57}$ Arnold, 11

58 lbid.
} 
Again we see the emphasis not only on the past in an abstract sense, but on a vision of the past as a means to access the future. This is where National Socialist temporality is most visible, in the regime's use of the past as a gateway to the future. The core philosophy at play is not simply one of historical understanding, but of historical situation - the process of identifying both a desirable past and future within which the present can be contextualized and a stable sense of continuity can be established. The application of academic fields in the pursuit of ideological rhetoric lent further legitimacy to the claims of Blut und Boden and helped cement NS cultural ideals in the mindset of the public, who, while not necessarily privy to the specifics of the regime's archeological programs, were always on the receiving end of a refined and temporally-inclined cultural message. This message formed part of a larger imagining of National Socialist culture, within and against which the architectural projects of the regime were to exist.

The NSDAP's image as an historic entity went beyond the operations of its political organs, permeating every facet of life, including the language of the regime's people. The historicity of National Socialism is observable in specific examples, such as the descriptor, "thousand year Reich," which not only resonated in contemporary discussions, but was also a remnant of this futureminded mentality that permeates popular histories of the period still-serving as a reminder of the regime's desire to project a vision of futurity. In more general terms there is evidence of this future-sightedness in both the everyday banality of 
the regime as well as its grander operations. In his work, Lingua Tertii Imperii : The Language of the Third Reich, the noted diarist Victor Klemperer describes the rise of temporally-sensitive language in everyday speech under the NSDAP. He writes,

[National Socialism] is so convinced of the permanence of its institutions, or at least it is keen to persuade others of that permanence, that every trifle, however insignificant, and everything it comes into contact with has a historical significance. Every speech delivered by the Führer is historical \{historisch\}, ... every meeting the Führer has with the Duce is historical, . . . every Party Rally, every feast day of any kind; and since the Third Reich seems to know nothing but feast days - you could say that it suffered, indeed was mortally ill, from a lack of everyday, just as the human body can be mortally ill from a lack of salt - it views every single day of life as historical. ${ }^{59}$

The subjugation of the everyday to this particular form of ideological selffashioning by the regime was a method of pressing National Socialist historicity onto the public. Radio broadcasts by party officials praised the longing for the regime's ascension exclaiming, "Everyday language is not enough to express what we feel in this emotionally festive hour." ${ }^{60}$ In this particular speech by Goebbels, the regime is continually painted as an "historic" entity. Speaking of the regime's successes in 1938, Goebbels notes, "There is no doubt that the year 1938 was unique in German history. It fulfilled a thousand-year dream of the German nation. ... All other political events pale before this historical fact. ... It

\footnotetext{
${ }^{59}$ Klemperer and Brady, 45; The full chapter, "The first three words of the Nazi language," is an interesting introduction to Klemperer's experience with the early adoption of NS influence in Germany. The section quoted above contains a much larger and more enthusiastic rendition of the quote.

${ }^{60}$ Goebbels, "New Year Address for 1939."
} 
will affect the most distant future." Goebbels goes on to complete his broadcast by saying, "We join at the end of this year in a single prayer from all Germans to the Almighty: May our people and Reich be eternal, and long live the Führer!"61 Goebbels begins this speech with an emphasis on the thousand year wait for National Socialism's arrival, and ends with a prayer for the everlasting continuation of the regime. This language of immortality and inevitability is common throughout the numerous speeches, broadcasts, and publications of the party. In a publication in the NS monthly Der Schulungsbrief published some thirty days after Goebbels' new year address the party is exalted for its historic arrival and the almost predetermined requirement for it's rise to power. The NSDAP is described as a regime "[t]hat made life and a future possible once more" and noted that, "[t]he worldview decision that came through the creative act of the National Socialist revolution ended a dying and weak age, bringing instead a new era ... [An] historic march."62 There was, in the language of National Socialism, a frequent use of religious tone and imagery that played on religious notions of predestination and the eternal - as well as those of a finite end and eschatological destruction and rebirth. ${ }^{63}$ Most importantly, NS language was one which sought to present the everyday as part of something greater, part of an organization larger than one's self. Ultimately, by consistently framing party

\footnotetext{
$61 \mathrm{lbid}$.

62 H. Mehringer. "Sieg Des Glaubens. Zum 30. Januar." Der Schulungsbrief, January 30, 1939. 63 The duality of the terminal and eternal in NS rhetoric is indicative not only of the contradictory nature of National Socialist rhetoric, but also of the desire to frame all aspects of the future around the movement.
} 
rhetoric and public oration around this grandiosity of scale, be it temporally or physically, the regime meant to place itself in a position of power, as part of the larger picture rather than the smaller components that comprised it.

In her article "Selfhood, Place, and Ideology in German Photo Albums" Maiken Umbach discusses the use of private photography as a counterpoint to the regime's imposed rhetoric of temporality. For the average citizen of the Third Reich, photography offered a means of preserving a present moment for an unknown future - an act of "pre-emptive commemoration." The creation of these personal photographs is similar to the creation of stately architecture in that it is a means of capturing the present for the future, or in the case of photography, the creation of personal lieux de mémoire. Umbach argues that, in the face of an uncertain future, photographs "privilege the generic over the idiosyncratic or original," but adds that even within these restrictions they offer a glimpse into the everyday lives of Germans. ${ }^{64}$ Through photographs we can witness the relative freedom of the subjects to create these memories and participate in the sharing of authority. She goes on to state that, "taking a photograph puts the photographer, as well as those who pose for the camera or help with the miseen-scène of the objects and spaces to be photographed, in charge of framing the meaning of the moment and how it will be remembered in the future." 65 In this instance however, the question of intent is very important. Umbach clearly states

\footnotetext{
${ }^{64}$ Maiken Umbach, "Selfhood, Place, and Ideology in German Photo Albums, 1933-1945," Central European History 48, no. 3 (September 2015): 335-65, 337.

65 Ibid., 340.
} 
that photographs are best understood in the context of examining "what National Socialism meant to people, rather than what it tried to do to people." ${ }^{\prime 66}$ Almost in antithesis to personal photography, the enforcement of rhetoric through architecture was an attempt on the part of the regime to instill meaning - to do rather than to create an interpretive space within which prospective audiences could make their own meaning ${ }^{67}$ Within this context, architecture offered a means of pre-emptive commemoration for the regime in much the same way that photographs did for individuals, however where photographs exist against the threat of an uncertain future, NS architecture had the benefit of a future imagined in a specific and anticipated way, a well-known future.

By marginalizing everyday activities and promoting the grandeur of historical acts in their place, the party was attempting to endow the public with a strong sense of the regime's historical importance. This in-turn reflected not only an emphasis on past events, but also the current regime's participation in the creation of a defined future. The creation of this future was an ongoing project that was altered but not fundamentally changed by the onset of the war. Prior to the outbreak of war, the project was undertaken in the form of festivals and speeches, and plans for future monuments. ${ }^{68}$ After the outbreak, the plans for stately monuments continued, albeit with less concrete completion dates, but the impetus for the historic took on a military tone, with battles and industrial

\footnotetext{
${ }^{66}$ Ibid., 337.

${ }^{67}$ Notably the actuality of the impact of this architecture is not the focus of this project, but rather the intended roles that it was to fill are.

${ }^{68}$ Klemperer and Brady, 45.
} 
triumphs taking their place amongst the showcase of historic events. ${ }^{69}$ In addition to the historisch, Klemperer also notes the importance of the eternal within National Socialist language. In rhetoric, the everyday was historical because the Reich was eternal, ${ }^{70}$ and so the actions of the party were part of the creation of this eternal regime. To facilitate this sense of eternality, the NSDAP borrowed from Christian texts and heralded Hitler as a stand-in for the Christ figure. ${ }^{71}$ The emphasis on the historical monumentality of the everyday and the everlasting qualities of the regime in common parlance, as described above, is a reflection of the level to which the NSDAP ascribed importance to their own definition of historicity. Not only were they aware of the impact that their own history had on managing the current state, there was also an understanding within the regime that they possessed the tools to ensure that future generations would reflect upon this foundational time and see only what the NSDAP of this early period wanted them to see. In this way, there was a sense of a pre-emptive editing of the state's history. ${ }^{72}$ Rather than having to edit the past in order to support the present, the NSDAP aimed to shift the point of revisal forward in time, sparing

\footnotetext{
${ }^{69}$ An example of this can be seen in the 1940 game Kennst Du sie? ...die Daten der Deutschen Geschichte ("Do you know that? Dates in German history"), which focused on teaching players historical events within the National Socialist revision of history. Players are rewarded for correct answers to questions like, "When did the great defensive battle in the West begin?," the answer to which, the game contends, is "The great defensive battle in the West, which at the same time was the greatest battle in world history, began on 10.5.1940, and revealed Adolf Hitler as the greatest military commander of all time." ; "Kennst Du Sie? ...die Daten Der Deutschen Geschichte ('Do You Know That?')," 1940. http://research.calvin.edu/german-propagandaarchive/kennst-du-sie.htm.

${ }^{70}$ Klemperer and Brady, 110-111.

${ }^{71}$ Bytwerk, 15.

${ }^{72}$ Hell and Schönle, 176.
} 
future iterations of the regime the effort of historical revision. In addition to saving the future from the toil of reshaping historical records, there was a desire to ensure that the future would have an historical record that strongly supported the continued existence of the regime. The regime's leadership understood that, as National Socialism was an ideology that drew so heavily on the past for legitimacy in its early years, there was a need for a favourable history upon which the NSDAP's orators and ideologues could draw. It followed that the regime of the future would also be aided by a robust legacy, and so evidence that the current regime sought for legitimacy began to be invented or adopted to fulfill this need for the future. This evidence came in many forms, including numerous recorded speeches exalting the historic rise of the movement, the reconstruction of traditional but undesirable architecture in towns like Rothenburg ob der Tauber, and most strikingly, the planned creation of grand architectural projects. ${ }^{73}$

One of the ways that the NSDAP's fledgling cultural myth was reinforced was by the grafting of National Socialist ideals onto existing cultural institutions, specifically the Church. Pre-existing facets of religious organizations in Germany were used in the regime's rhetoric to reimagine Hitler and National Socialism as a replacement for the socio-cultural space occupied by religion. Mosse argues

\footnotetext{
73 In a speech given in Hamburg on March 20, 1936, Hitler announced, "I do not want to blindly ignore the great and historic deeds and accomplishments of this history but on the contrary, wish to respect everything which past generations have accomplished, including the historical formation of our nation, in the hope that so many more coming generations will also respect what it is we propose to accomplish." ; Adolf Hitler and Max Domarus, Speeches and Proclamations, 1932-1945 (Wauconda, IL, U.S.A: Bolchazy-Carducci, 1990). 237.
} 
that the language used by the NS to describe its leadership borrowed heavily from that used in religious circles, citing Goebbels's use of "the miracle of belief" and adherence to Mein Kampf as a "sacred book." Mosse also notes that Hitler was often referred to as a "savior," and his followers as "apostles." ${ }^{4}$ There was particular effort to shape Hitler into a saviour figure made by Nazi propagandists, including Goebbels, who personally noted in his diary that, "when the Fuhrer speaks, it is like a religious service"; ${ }^{75}$ Alfred Rosenberg, who, despite staunchly anti-Christian sentiments, nevertheless promoted a new religion under National Socialism in which, in his words, "the men of the coming age will transform the hero's memorials and glades of remembrance into the places of pilgrimage of a new religion"76; and Hitler himself, who lived within a saviour complex of his own creation that was fed by his admirers in the party and the public that followed them. The rhetoric and imagery that went into creating - what lan Kershaw calls "the Hitler Myth"77 was laced with historically-minded allegory and featured a temporally-inclined metanarrative. The resulting fervor that was created in the public arena stemmed from a cult of personality around the person of the Führer.

The Hitler myth was a cultural movement that encompassed existing social structures in order to extend its scope across all strata of the perceived National Socialist citizenry. In her book, The Aryan Jesus: Christian Theologians

\footnotetext{
${ }^{74}$ Mosse, 235.

${ }^{75}$ Ian Kershaw, The "Hitler Myth": Image and Reality in the Third Reich (Oxford : New York: Clarendon Press ; Oxford UniversityPress, 1987), 108.

${ }^{76}$ Rosenberg, Alfred, as quoted in Richard Steigmann-Gall, "The Holy Reich": Nazi Conceptions of Christianity, 1919-1945 (New York: Cambridge University Press, 2003), 86-87.

${ }^{77}$ Kershaw, 2.
} 
and the Bible in Nazi Germany, Susannah Heschel discusses the formation of das Institut zur Erforschung und Beseitigung des jüdischen Einflusses auf die deutsche kirchliche Leben ("The Institute for the Study and Eradication of Jewish Influence on German Religious Life"), and traces the formation of the institute and the process by which the institute attempted to Nazify religion in Germany. One of the many ways in which this Nazification was undertaken was to bring together scripture and the rhetoric of the party and to build identifiable linkages between scripture and the contemporary actions of the regime. In 1933 Walter Grundmann, the director of the institute, sermonized on the rise of Hitler to office, declaring Hitler to have fulfilled the biblical prophecy of Jesus' second coming. ${ }^{78}$ In a pamphlet published in February 1933 Grundmann wrote,

[Hitler] is in himself completely one ... We also know that the power of such a clear and truthful man does not derive from the earth, but rather out of that higher world that the Master, Christ, called the kingdom of heaven. ... This oneness of man with his God is a symbol of what the old church teachers intended to say with the Trinity. ${ }^{79}$

Grundmann's sermon describes Hitler as, in the words of Heschel, "fulfilling Isaiah's eschatological promise." ${ }^{80}$ Grundmann and his cohort in the institute placed their own time, elucidated by the ascension of the NSDAP, as part of the continuing passage of cosmic ages, around which the fundamental Christian understanding of time hinged. To further the totalizing goal of cultural-temporal

\footnotetext{
${ }^{78}$ Susannah Heschel, The Aryan Jesus: Christian Theologians and the Bible in Nazi Germany (Princeton University Press, 2008), 190.

${ }^{79}$ Grundmann, Walter, as found in Heschel, 190-191.

${ }^{80}$ Heschel, 190.
} 
hegemony, the myth of the Fuhrer assumed the stewardship of pre-existing religious systems and aimed to co-opt the roles that they fulfilled in society, specifically that of a prophesied leader and the coming transition of ages In doing so, the regime gained access to an additional wellspring of temporally inclined imagery and cultural heritage.

As mentioned, another place where the emphasis on time and continuity is in organized religion. Of particular note for this context is the concept of protestant millenarianism. The specific strain of Millenarianism in question here is that of Millennialism, specifically the theory of Three Ages. ${ }^{81}$ The impact of religion on modern, western perceptions of time is obvious: time is divided by the life and death of a Christian figure. This bisection of history into $B C$ and $A D$ (though now commonly referred to as BCE for Before Common Era) is, of course, not the only means of dividing time. In the twelfth century, Joachim of Fiore established a trinary division which he based on his reading of the Book of Revelations. This new division was based upon the histories found in scripture and the foundational teaching on the holy spirit. The three periods were: the Age of the Father, as depicted in the Old testament; the Age of the Son, as depicted in the New Testament; and the Age of the Spirit, which was believed to begin in the then-nearing future of $1260 .{ }^{82}$ While Joachim of Fiore's ideas were later

\footnotetext{
${ }^{81}$ Millenarianism is a broader term that describes beliefs which specifically focus on the coming of a thousand years of prosperity after a contemporary period of prolonged desolation and degeneration. Notably, Millenarianism does not exclusively denote religious beliefs but can also describe any social organization of belief.

82 Tony Lane, Concise History Of Christian Thought, A, Revised edition (Grand Rapids, Mich: Baker Publishing Group, 2010), 115.
} 
rejected by the Church, they gained renewed favor after the Reformation, and were, in the words of Tony Lane, "influential on some of the fringe Anabaptist groups at the Reformation - and to some extent on mainstream Protestantism." 83 Millennialism took the ideas of the Three Ages and expanded upon them, incorporating strong eschatological ${ }^{84}$ and utopian motifs, and presenting a more specific thousand-year age of paradise following the previous periods of turmoil.

There are clear overlaps between millennial theology and National Socialist rhetoric. The German nationalist author Arthur Moeller van den Bruck published Das Dritte Reich ${ }^{85}$ in 1923, in which he framed Germany's post First World War situation in the context of a millennial second age ${ }^{86}$ The influence that van den Bruck's work had on National Socialist visions of the future are noteworthy, and in some instances, obvious: the term "Third Reich," for example, is derived from van den Bruck's book title. National Socialism was very much a millennial institution: it consistently employed motifs of rebirth and the revitalization of the country, presented itself as ushering a new age of prosperity, relied on the imagery and pomp of a messianic leader, and underscored its rhetoric with apocalyptic imagery. This connection has been made before.

Richard A. Landes discuss the NSDAP's application of millennial ideas in his

\footnotetext{
83 Ibid., 116.

${ }^{84}$ Eschatology is the theological study of the end of time.

${ }^{85}$ Directly this translates to "the Third Empire," however the English title of the book is translated as "Germany's Third Empire."

${ }^{86}$ Arthur Moeller Van Den Bruck, Germany’s Third Empire (Arktos, 2012), 17.
} 
work The Encyclopedia of Millennialism and Millennial Movements, where he writes,

The acceptance of Nazism as a millennial faith was experienced by many followers as a conversion experience. Disoriented by the rapid change and chaos of the Weimar period, many future Nazis felt lost and hopeless. After attending a Nazi gathering and listening to speeches, reading Nazi literature, or listening to a Nazi proselytizer at work or at their home, many individuals reported experiencing a profound spiritual transformation. They felt themselves move from darkness to light, from confusion to clarity. Hitler's simplification of the complexities of modern life, a simplification rooted in the symbolism of millennial, messianic, and apocalyptic imagery and rhetoric, reordered their collapsed perception of reality. ${ }^{87}$

Landes notes messianic and apocalyptic imagery as tools of Hitler and the NSDAP, however it is important to consider that these are inherently themes of millennialism, which itself functions on the belief in the passage of time from poor age to prosperous age, as heralded by a spiritual figure. Key to National Socialist Millennialism was Hitler as a stand-in savior. There had been a definite culture of hero worship in the imperial period, with Wilhelm II framed as an historical symbol of great spiritual importance, however this paled in comparison to the position Hitler held during the Third Reich. ${ }^{88}$

Hitler's place as a messianic figure is easily observed: he is frequently discussed in terms of his divine authority and power. Herman Göring said of Hitler, "we National Socialists declare with complete conviction that for us, the

${ }^{87}$ Richard Landes, ed., Encyclopedia of Millennialism and Millennial Movements (New York: Routledge, 2000), 497.

${ }^{88}$ Kershaw, 15. 
Fuhrer is infallible in all political and other matters that affect the people's national and social interests." ${ }^{89}$ Bytwerk also presents one soldier's comments on Hitler as indicative of the spiritual hold he had on the nation, "our Fuhrer is the most unique man in history. I believe unreservedly in him and in his movement. He is my religion."90 The April 20th edition of Das Schwarze Korps ("The Black Corps") - the official newspaper of the SS - published an article entitled "Er ist der Sieg," or "He is Victory!," in which the author exalts Hitler on his divine and superhuman qualities, saying that he "knows his people and their souls out of a deep, almost prophetic knowledge." 91 In the NSDAP's visual propaganda Hitler is also portrayed as the spiritual saviour of the nation, with images of Hitler often mimicking religiously informed art of previous centuries. Images like those below represent some of the many religious depictions of Hitler in art.

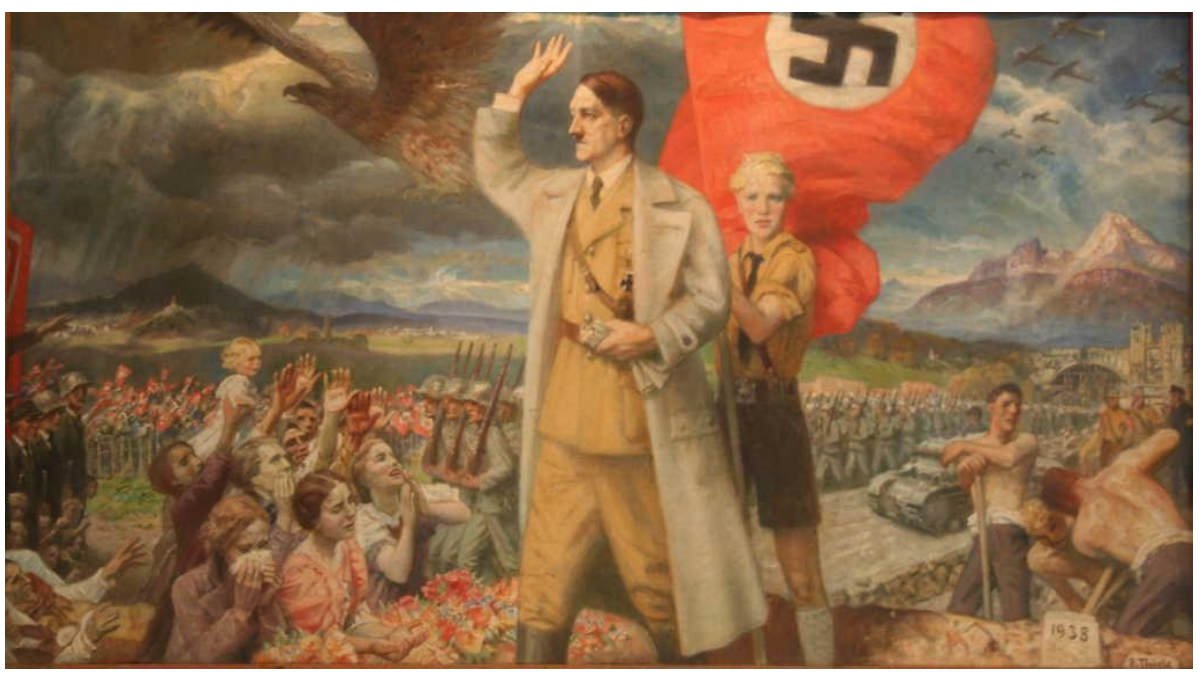

Figure 1 - Portrait of Hitler by F. Thiele. This painting was found in a bombed-out beer hall in Munich by an Allied soldier during the post-war occupation. [from Bytwerk, "Hitler in Nazi Art."]

${ }^{89}$ Göring, "Untitled Editorial.," as cited in Bytwerk, Bending Spines.

90 Bytwerk, 15.

91 “Er Ist Der Sieg." Das Schwarze Korps, April 20, 1944. 


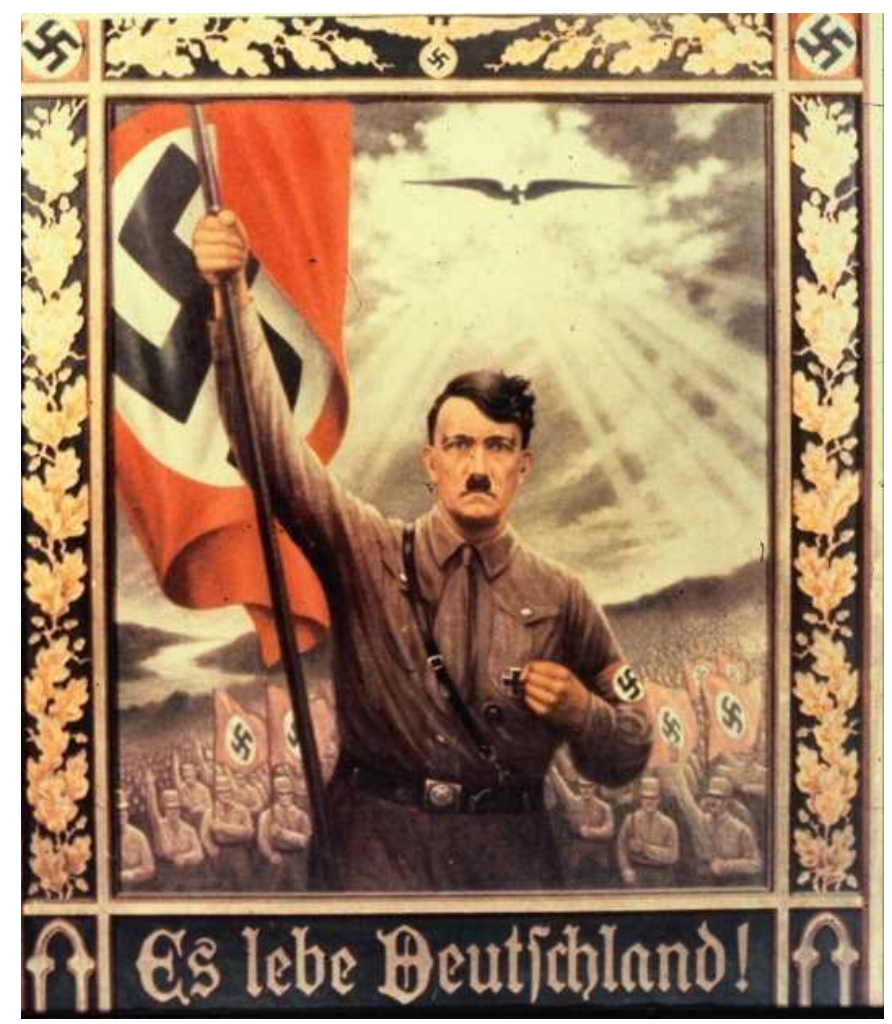

Figure 2 - Portrait of Hitler with heavy religious motifs. This painting is thought to have been produced in the 1930s. The text reads, "Long live Germany!" [from Bytwerk, "Hitler in Nazi Art."]

Hitler himself spoke of his own role in the regime in terms of a spiritual duty, noting that in his mission bring about NS rule was acting in accordance with the divine.$^{92}$ The adoption of a personally pro-Christian persona brought adoration and comfort to religious Germans who feared the aggressive atheism of other sects of the party, including the radical religious-spiritual movement of Positive Christianity, which functioned under the same racial logic of "blood and soil" and sought to incorporate the paganistic mythos favoured by the likes of Alfred Rosenberg, Robert Ley, Richard Walther Darré, and Baldur von

92 Hitler and Foxman, 65. 
Schirach..$^{93}$ The party's co-option of the Church and attempt to install the more spiritually traditional - when compared to the rhetoric of Positive Christianity Reichskirche ("National Reich Church") was done so as a means to further assuage religious Germans of the party's devotion to their traditional, Christian, ideals. ${ }^{94}$ Ultimately the use of Hitler as a religious leader, and the subordination of the Church to the regime not only helped to unify Germans both within the party and under its rule, but also reinforced the millennial narrative of a changing epoch, one which the new leader would bring Germans out of the immediate dark past into a bright and long-lasting future. ${ }^{95}$

A seemingly obvious schism in NS rhetoric concerned the perceived longevity of future National Socialist rule. When looking at the language and oratory there is a seemingly endless expanse of time in which National Socialism will prosper, and yet discussions of the eternal Reich and an endless age of prosperity seem contradictory when juxtaposed against the stark eschatological ramifications of the regime's millennial ideology. Millennialism is inherently apocalyptic in nature, with a golden age of prosperity ultimately ending in totalizing devastation to be followed by an indefinite, though otherworldly paradise. ${ }^{96}$ How can the regime be both eternal and yet ascribe to a myth of

\footnotetext{
${ }^{93}$ Doris L. Bergen, "'Germany Is Our Mission—Christ Is Our Strength!'The Wehrmacht Chaplaincy and the 'German Christian' Movement," Church History: Studies in Christianity and Culture 66, no. 3 (1997): 522-36, 535; Steigmann-Gall, 21-22, 86-87.

94 Bergen, 522-523.

${ }^{95}$ Kershaw, 27; Angela Astoria Kurtz, "God, Not Caesar: Revisiting National Socialism as 'political Religion,"' History of European Ideas 35, no. 2 (June 2009): 236-52, 241.

${ }^{96}$ This understanding is often primarily derived from Revelation 20:1-6
} 
terminal existence? The duality of NS rhetoric lies in the impetus of National Socialism as the universal culture-bearer, as a sole champion of civilization surrounded by a "hostile environment." ${ }^{\text {97 }}$ In 1944 Goebbels delivered a speech emphasizing a particularly heightened awareness of this situation following the Soviet's victory at Stalingrad, noting that Germans "know [their] historic responsibility. Two thousand years of Western civilization are in danger." 98 Divorced from the context of the war and the approaching Soviet forces NS culture had established itself as being very aware of a possible end to the regime. This end was not simply envisioned as the fall of National Socialism, but would be the end to all civilization: National Socialism was equated with the very essence of society and the continued existence of history-makers. In response to this totalizing potential, the regime turned to one of its leader's personal obsessions, architecture, to better combat the prophesied conflagration of ideas. It is here that the NSDAP used architecture, and the prospect of lasting built cultural icons, to combat their own mortality as a civilization. ${ }^{99}$

National Socialism as a cultural entity and movement was obsessed with its own place in time. As the organization had attempted a totalizing authority over its people, so did it apply the same vigor to its own culture and history. Originating from the minds of its highest ranking members and affiliates, the NSDAP possessed a culture deeply invested in its own history and futurity, one

\footnotetext{
97 Speech on September 12, 1938 from: Hitler and Domarus, 1151.

98 Goebbels, Joseph. "Nun, Volk Steh Auf, Und Sturm Brich Los! Rede Im Berliner Sportpalast." In Der Steile Aufstieg, 167-204. Munich: Zentralverlag der NSDAP, 1944.

${ }^{99}$ Hell and Schönle, 176.
} 
which used the ideologies of party elites to construct a temporally-sensitive and pervasive culture of continuity. Central to the regime's mandate and social persona was the sense of continuity - not simply as a continuation of the past, or as a group worthy of the future, but of an institution upon whose existence time and civilization hinged. National Socialism was the bearer of culture, an institution whose end was not viewed solely in terms of catastrophe for Germany but in a total collapse of society and civilization at large. Evidence for the regime's sense of historicity and future-mindedness can be seen in the personal and public discourse of party members, the propaganda of the regime, the common parlance of those living under National Socialism, and the adherence and co-option of existing temporally-sensitive religious organizations. Finally, the seemingly contradictory ideas of everlasting reign and eschatological ruin were combated through the creation of built cultural icons that functioned to preserve National Socialism using this existing system of historicity and temporallysensitive cultural guideposts, themes that will be discussed in greater detail in chapter 3. 


\section{Chapter 3 - Sites of Temporality}

In 1925 Hitler wrote about his vision for architecture under National

Socialism. He argued,

Our big cities of today possess no monuments dominating the city picture, which might somehow be regarded as the symbols of the whole epoch. This was true in the cities of antiquity, since nearly every one possessed a special monument in which it took pride. The characteristic aspect of the ancient city did not lie in private buildings, but in the community monuments which seemed made, not for the moment, but for eternity, because they were intended to reflect, not the wealth of an individual owner, but the greatness and wealth of the community ... The few still towering colossuses which we admire in the ruins and wreckage of the ancient world are not former business palaces, but temples and state structures; in other words, works whose owner was the community. ${ }^{100}$

For Hitler, and the NSDAP, architecture represented a tangible source of cultural capital, one which functioned within the regime's network of temporally sensitive cultural signifiers. In this chapter I trace the development of state architecture in the period leading up to the rise of National Socialism and offer a socio-political context for architecture as a cultural and historical practice in Germany up to that point. I examine several architectural sites which serve as exemplars of the NSDAP's own temporally sensitive architecture including the Reichsparteitagsgelände in Nuremberg, the Reichssportfeld in Berlin, as well as the proposed site of Welthauptstadt Germania - specifically the envisioned location of a First

100 Hitler and Foxman, 264-265. 
World War Triumphal Arch and the current resting place of the Schwerbelastungskörper in northwestern Tempelhof, Berlin. I examine each site as an example of National Socialist architecture created with a specific temporal-rhetorical inclination, and which were designed to function under National Socialist cultural conditions. I argue that the emphasis placed upon the historic past and the far future within the design and aesthetic of these projects reflects more than a simple adherence to contemporary stylistic trends, but rather, is evidence of a National Socialist worldview that understood the NSDAP and its movement as part of a larger historical entity, within which architecture played a key role in the production of a particular culture of historicity.

As I have discussed in Chapter 1, there is a tendency to classify National Socialist architecture as belonging to one of several existing design aesthetics, namely neoclassicism or modernism. While - as we will see - these styles were often incorporated into the envisioned final products of the regime, the NSDAP did not pioneer the act of architectural appropriation in Germany, but rather, built on established legacies of incorporating existing styles into their own unique aesthetic. To clarify, viewing architecture in this way is to emphasize how built works, whose designs were not solely a reflection of their creator's cultural proclivities, served as part of an active network of cultural curation aimed at creating and reinforcing specific ideals amongst a landscape of shifting cultural norms. Here I present a brief history of the architectural trends present in 
Germany leading up to the advent of National Socialism, however my intent is not to fall into the same trap of simply describing NS architecture solely as a continuation of existing trends. Rather, I aim to explore how the NSDAP built upon a legacy of historically sensitive architecture and continued to manipulate popular designs to fit into their own narrative of historicity. Of particular importance in this context is the use of the future in addition to the past in the conceptualization of National Socialist projects. Whereas the earliest examples used antiquity as an historical benchmark and a means of hearkening to the past for cultural-political reasons, the NSDAP employed these ancient styles not only to suggest a common lineage of strength, but also of imagined future legacy.

Europe's fascination with the aesthetics of antiquity during the 19th and early 20th century was an interesting counterpoint to the rise of modernism and those visions of a rapidly approaching future. Where modernism offered a means of grasping at the future through artistic expression - one which sought to be at the forefront of technology and a perceived social progress - neoclassicism was often a reactionary force which looked to the distant- as a means of confronting the immediate past.

German neoclassicism arose out of the early post-Enlightenment period, wherein the revival of classical aesthetic ideas occurred alongside a renewed interest in pre-Baroque architecture, on which many German towns were modeled. ${ }^{101}$ The medieval bulwarks and stone walls that defined much of

101 Johann Joachim Winckelmann is considered one of the leading persons behind the Neoclassical movement in Germany. His works, Gedanken über die Nachahmung der 
German village life were reimagined by Neoclassical architects, who - according to David Watkin, "responded imaginatively to the challenge of turning the zig-zag lines of the fortifications into picturesque Elysian fields surrounding the towns as a green belt."102 The popularity of all things English and the spread of humanist ideas during this period helped spur on the Neoclassical trend in German architecture, which was a manifestation of the perceived Grecian ideals of freedom, truth, and humanity. ${ }^{103}$

An earlier example of Germany's politicization of evocative historical architecture may be found in the designs of Karl Friedrich Schinkel, a prominent Prussian painter and architect of the late 1700 s and early 1800 s whose inclination toward an aesthetic reminiscent of the ancient Greeks helped drive German neoclassicism and promote Prussian nationalism. Schinkel's architectural works were a reflection of his time: following the occupation of Berlin by the French Revolutionary army there was a disdain amongst German artists and intellectuals for the styles of Latin antiquity, which was a preferred look under

\footnotetext{
griechischen Werke in der Malerei und Bildhauerkunst ("Thoughts on the Imitation of Greek Works in Painting and Sculpture"), Anmerkungen über die Baukunst der Alten ("Remarks on the Architecture of the Ancients"), and Geschichte der Kunst des Alterthums ("History of Ancient Art") represent some of the seminal art history texts the 18th century. In "Thoughts on the Imitation of Greek Works" Winckelmann proclaims that, "there is but one way for the moderns to become great, and perhaps unequalled; I mean, by imitating the ancients. And what we are told of Homer, that whoever understands him well, admires him, we find no less true in matters concerning the ancient, especially the Greek arts." ; Johann Joachim Winckelmann and Henry Fuseli, Reflections on the Painting and Sculpture of the Greeks: With Instructions for the Connoisseur, and an Essay on Grace in Works of Art (London: Printed for the Translator, and sold by A. Millar, 1765), 2.

102 David Watkin and Tilman Mellinghoff, German Architecture and the Classical Ideal, 1st MIT Press ed (Cambridge, Mass: MIT Press, 1987), 9.

103 Ibid., 11.
} 
Napoleon. ${ }^{104}$ Grecian antiquity presented an out for those Germans with a vested interest in the burgeoning Neoclassical style in that they represented similar antique qualities but did not represent cooperation with the French. Schinkel's work was also heavily influenced by his time spent traveling in England where he, like many Germans there, was confronted by a lack of the aforementioned medieval walled towns. The relative freedom of movement between urban centers was out-of-line with life in Prussia and the various German principalities. In England, Schinkel was witness to the eclectic mixing of styles that occurred in contemporary English architecture. This eclecticism did not profoundly affect Schinkel, whose time, Posener argues, "no longer possessed a common style in architecture." 105 The adoption of a Greek style by Schinkel and other German architects was done so within this framework of eclecticism, and was a repurposing of the style for their own ends rather than a straightforward cloning of aesthetic and intent. German architects, countering their French aggressors, called upon an imagined second renaissance and in doing so, offered a means of promoting an idealized "Prussian" take on architecture. This nationalistic approach to architecture, utilizing antiquity as an aesthetic guidepost for creating new structures exalting the Prussian state, became the vogue for architects during the coinciding literary and cultural period aptly named Weimarer Klassik

\footnotetext{
104 Julius Posener, From Schinkel to the Bauhaus: Five Lectures on the Growth of Modern German Architecture, Architectural Association. Paper No. 5 (London: Lund Humphries for the Architectural Association, 1972), 14; lain Boyd Whyte, "Charlottenhof: The Prince, the Gardener, the Architect and the Writer," Architectural History 43 (2000): 3, 5.

${ }^{105}$ Posener notes that, "Eclecticism may be defined as freedom to use styles of the past."; Posener, 13.
} 
("Weimar Classicism"). As an architectural style, Classicism helped establish

Prussia as a strong, historically redolent state whose artistic works provided a visible symbol of power and connection to a romanticized past. ${ }^{106}$ The linkages between the ancient Grecian civilization and Prussia created by these Classical works meant that Germans could look to their rulers - and the works they sponsored - as a source of the same civilization and fortitude that was popularly identified in antiquity. ${ }^{107}$ Likewise, the contrast between Grecian and Latin antiquity furthered the nationalistic spirit of resistance against France and other outside influences.

The end of the 19th century saw a shift away from neoclassicism toward modernism, however in Germany the preference for the antique remained strong. The collapse of the Kaiserdom and the advent of the Weimar period saw a sharp rise in Modern style, however some notable Neoclassically disposed architects still remained, including Gerdy and Paul Troost and the young Mies van der Rohe - all of whom would be involved with the National Socialist movement in some form or another- as well as the ever-noted Albert Speer.

In antithesis to classicism, modernism and modern art evoked feelings of change and of a new way to artistically conceive of the universe as well as an emphasis on the unknown quality of the future. Modern style grew in popularity during the early part of the 20th century and following the conclusion of the First

\footnotetext{
106 Whyte, 13, 21.

${ }^{107}$ Martin Steffens, K. F. Schinkel 1781-1841: An Architect in the Service of Beauty (Taschen, 2003), 11, 44.
} 
World War, European artists used Modern aesthetics to help reshape the postwar world, in-particular using the future-ness of modernism to present their vision of the future as it related to the reconstruction of Europe. On a state level, the application of modern technologies and Modern style led to the production of built works that depicted refreshed and contemporary states with revitalized national interests. In notable contrast to its state building uses, private artists employed Modern techniques in their creations to present their dissatisfaction with the state of Europe and the horrors of the recent war, with a specific emphasis on reflecting on contemporary European society. ${ }^{108}$ Despite existing anti-war sentiments within much of the visual Modern art movement the technically advanced nature of the architectural Modern aesthetics resonated with hardline traditionalist groups like the NSDAP. The use of new visual forms, combined with a radically different approach to traditionally held artistic beliefs made the Modern movement a point of contention for many artists and intellectuals of the time. Notwithstanding this, modern construction techniques and materials expanded the creative possibilities for the state's architectural productions. Notably, this aesthetic would become a key aspect of the styles of some of the National Socialist movement's leading artists ${ }^{109}$ and architects, often supplanting or altering existing Neoclassical proclivities. ${ }^{110}$

\footnotetext{
${ }^{108}$ See the works of Conrad Felixmüller, Otto Dix, and Henry de Groux for examples of this theme.

109 Peter Paret, German Encounters with Modernism: 1840-1945 (New York: Cambridge University Press, 2001), 212.

110 Taylor and Will, 135-136.
} 
The NSDAP had its own stylistic preferences in addition to the continent wide trends of classicism and modernism. A third style of architecture favored within National Socialist circles - although less discussed in terms of its relationship to the future - was that of the idealized medieval Volk. The volkish style represented an idyllic Aryan racial past, one which situated itself in a romanticized medieval history, and which represented an identifiable link between the imagined past and desired future. The use of volkish architecture can be seen in National Socialist projects of "beautification" undertaken in rural villages like Rothenburg ob der Tauber, which in the late 1930s became the focus of the German Labour Front's Kraft durch Freude (Strength Through Joy) program. Rothenburg became one of the Reich's vacation hotspots and was promoted by the $K d F$ as "a shining monument to German community in olden times." 111 In the case of Rothenburg, "beautification" meant the removal of all foreign architectural styles from the village core and the overall repurposing of the town into a quintessential National Socialist exemplar. The NSDAP's use of volkish aesthetic is further evidence of their desire to edit the contemporary world in order to make real their imagined history, not only for themselves, but as part of a greater desire to promote a narrative of continuation from the past to the future. Here we can identify the regime's persistent desire to create lieux de mémoire, which were done so with the intent of fabricating a history more

\footnotetext{
111 Joshua Hagen, "The Most German of Towns: Creating an Ideal Nazi Community in Rothenburg Ob Der Tauber," Annals of the Association of American Geographers 94, no. 1 (2004): 208.
} 
accepting of contemporaneous Nazi values. In the Rothenburg example, the reimagining of the town's construction as untouched by "foreign" influence went toward recreating the local narrative of an unspoilt German community whose existence was a tangible linkage between the current government and its halcyon ancestry.

The architectural legacy of pre-National Socialist Germany was not completely undone with the regime's rise to power. In addition to the National Socialists' iconic state building works there were many architectural projects undertaken in Germany whose style did not necessarily conform to the artistic ideologies of the party. These projects were part-and-parcel of the European post-war reconstruction and development and so were less politicized to the extent of the regime's monumental works. While everyday buildings outnumbered state sponsored construction projects, it was the grand, outwardly Neoclassical/Modern structures which drew the most attention (both within and outside the Reich) and which became synonymous with the regime's architecture. ${ }^{112}$ In the following section, I present a more detailed exploration of several of these structures and place them within the context of National Socialism's temporally sensitive culture.

As previously mentioned, in this brief analysis I will examine three specific sites of National Socialist architecture. These include Reichsparteitagsgelände ("Nazi party rally grounds") in Nuremberg, the Reichssportfeld complex in Berlin,

112 James, German Architecture for a Mass Audience, 91. 
as well as the proposed site of Welthauptstadt Germania ("world capital Germania") - specifically the resting place of the Schwerbelastungskörper ("heavy load-bearing body") in northwestern Tempelhof, Berlin. I argue that these envisioned projects were designed not only as physical notations of the current regime's power and ideology, but as beacons of cultural capital which operated within a network of temporally inclined, National Socialist cultural touchstones.

The first site I explore is that of the Reichsparteitagsgelände in Nuremberg, which was designed to host the NSDAP's annual party rallies. The Reichsparteitagsgelände hosted the rallies from 1933 until 1938, only ending the tradition due to the outbreak of war with Poland. The site contained several buildings representative of the party's historicity and specifically future-minded approach to architecture. First among these is the Zeppelinfeld, and particularly the Zeppelinhaupttribüne (main tribune). The Zeppelinfeld is notably one of Albert Speer's first commissioned works for the NSDAP and was the primary location of Leni Riefenstahl's film Triumph of the Will. The Second structure, the Kongresshalle, was never completed. It is located at the entrance to the rally grounds and was built as a reflection of the party's "Doric" preferences: designed to seat approximately 50000 guests, the parabolic structure was built to emulate the great colosseum in Rome. ${ }^{113}$ The final structure of note at the Reichsparteitagsgelände is the Deutsches Stadion which, at 400000 seats $^{114}$,

\footnotetext{
113 Scobie, 80.

${ }^{114}$ Historian Robert R. Taylor notes that while Gerdy Troost claimed the stadium could hold nearly 500000 people seated, Albert Speer states that only 300000 would be possible. The 400 000 person figure shown here is found on the official placards at the site itself, although how the
} 
would have been the largest capacity stadium in the world, even by today's standards. ${ }^{115}$ While the foundation was laid, the project never progressed any further than the initial excavations and the excavation pit has since been repurposed into the Silbersee lake, a local green space. The structures at the Reichsparteitagsgelände were constructed between 1935 - 1937.

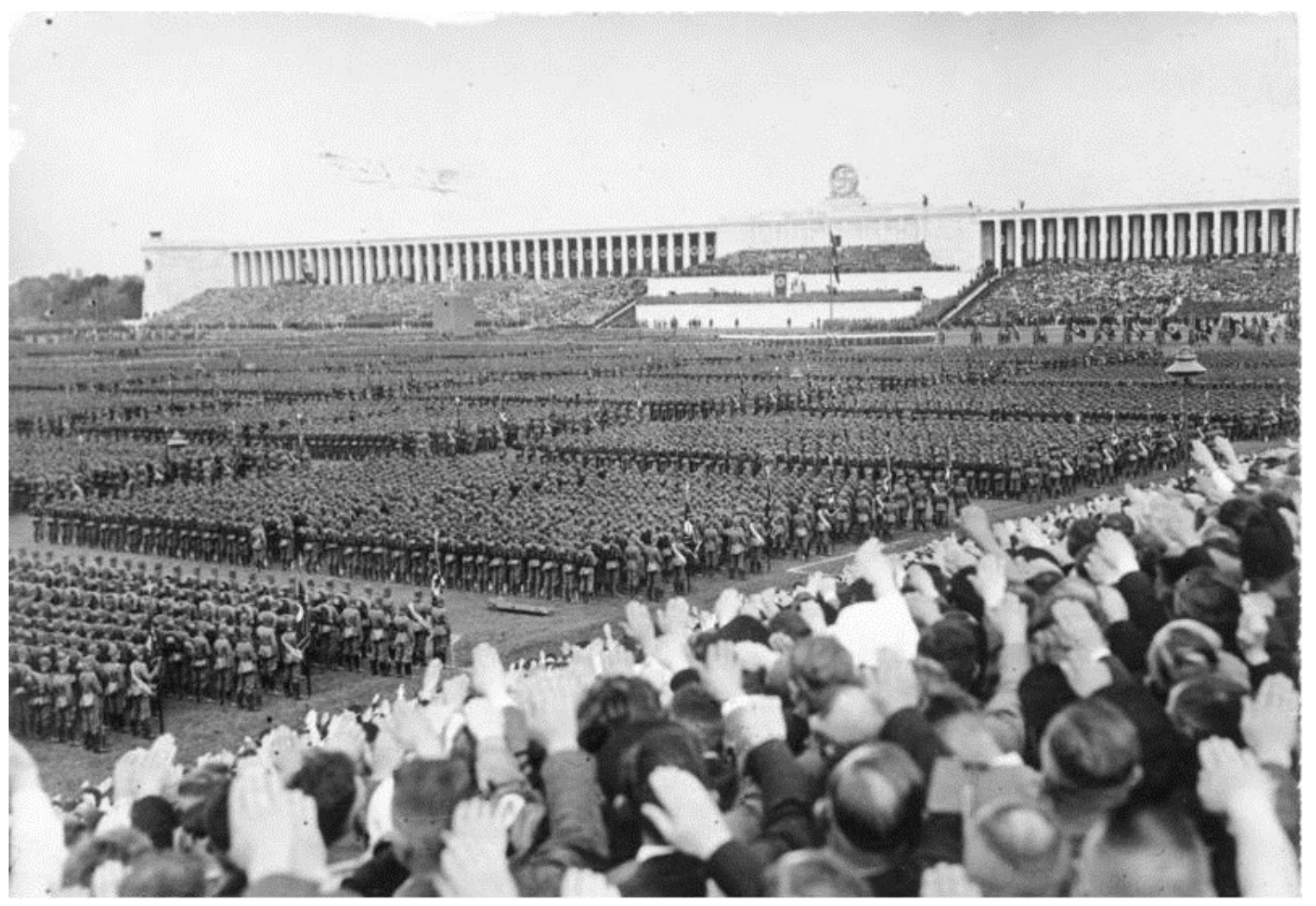

Figure 3 - A rally at the Reichsparteitagsgelände with the Zeppelinhaupttribüne depicted. [Bundesarchiv Bild 183-C12701, Nürnberg, Reichsparteitag, RAD-Appell]

The foremost - and only completed - building at the

Reichsparteitagsgelände was the Zeppelinfeld. Outwardly, the physical structure of the Zeppelinfeld was built in the vein of ancient Rome. The Zeppelinfeld

site coordinators derived this exact number is unknown; Taylor, The Word in Stone, 172 (footnotes).

115 On-site info-panel, Silbersee Nuremberg. 
consisted of a large rally grounds surrounded on three sides by raised earthen mounds upon which stone grandstands rested. The capacity of the Zeppelinfeld was around 200000 , with the space for some 90000 on the central parade ground, 64000 in the grandstands, and another 60000 on the Zeppelinhaupttribüne. The internal space of the Zeppelinfeld measured 90480 square meters, and was surrounded by 66 large stone towers that were spaced evenly through the grandstands, and upon which were positioned six flagpoles. ${ }^{116}$ The whole site served as a less formal gathering space than the proposed Deutsches Stadion or Kongresshalle. ${ }^{117}$ The Zeppelinfeld's space served the regime well as a place to congregate, however it is the Zeppelinhaupttribüne ${ }^{118}$ that should be considered the site's primary architectural focus. The Haupttribüne was roughly 360 meters wide, and was constructed to evoke the imagery of the Pergamom Altar, an ancient Greek structure that once resided at the acropolis and since 1901 was housed on the Museum Island in central Berlin. The building was constructed using brick and concrete with a facade of limestone. ${ }^{119}$

As I have noted, the Zeppelinfeld was Speer's first foray into what would become his signature monumental architectural style. Speer described the impact that his work on the Zeppelinfeld, and in particular his close artistic

\footnotetext{
116 Speer, Albert Speer, 165.

117 Lane, Architecture, 193.

118 Shortened to Haupttribüne, or alternatively, Zeppelintribüne

119 Zeppelintribüne (Nünburg, Bayern: Dokumentationszentrum Reichsparteitagsgelände, n.d.) information panel.
} 
association with Hitler, had on his conception of NS architecture. The NSDAP, above all Hitler, understood the didactic possibilities of architecture. ${ }^{120}$ Working closely with Hitler, Speer gained a sense of what the man, and ultimately the movement, needed from the architect's designs. ${ }^{121}$ Hitler spoke of architecture functioning as a means of connecting timescapes, and Speer aimed to use this opportunity to shape his architecture to fulfill Hitler's desires for such temporally inclined edifices. ${ }^{122}$

In her work, Macdonald discusses the Zeppelinfeld and its place in the post-Nazi world, specifically examining the ways in which modern Nuremberg negotiates its Nazi past. ${ }^{123}$ She discusses the creation of temporal connections through architecture, and notes Speer and Hitler's preoccupation with creating "bridges of tradition" to speak between the ages, ${ }^{124}$ however as with much of the contemporary literature, Macdonald's discussion of NS temporality and architecture situates its analysis in a post-Nazi world. ${ }^{125}$ By framing their work in a contemporary setting, authors such as Paul Jaskot and Joshua Hagen are able to ask important questions of NS legacy, particularly in regards to the crimes of

\footnotetext{
${ }^{120}$ Sharon Macdonald, Difficult Heritage: Negotiating the Nazi Past in Nuremberg and Beyond (Routledge, 2010), 41-42.

${ }^{121}$ Macdonald, "Words in Stone?" 108-109.

122 Paul B. Jaskot, The Architecture of Oppression: The SS, Forced Labor and the Nazi Monumental Building Economy, The Architext Series (London; New York: Routledge, 2000), 114 ${ }^{123}$ Macdonald, "Words in Stone?" 106.

124 Ibid., 113.

125 Thomas Friedrich, Hitler's Berlin: Abused City (New Haven: Yale University Press, 2012).; Joshua Hagen and Robert Ostergren, "Spectacle, Architecture and Place at the Nuremberg Party Rallies: Projecting a Nazi Vision of Past, Present and Future," Cultural Geographies 13, no. 2 (2006): 157-181.; Joshua Hagen, "Architecture, Symbolism, and Function: The Nazi Party's 'Forum of the Movement," Environment and Planning D: Society and Space 28, no. 3 (June 2010): 397-424; ; Jaskot; Macdonald, "Words in Stone?" ; Macdonald, Difficult Heritage.
} 
the regime and how modern audiences reflect upon their works in this context. Just as Maiken Umbach has argued that we need to examine what National Socialism "meant to people, rather than what it tried to do to people,"126 my own work seeks to combine these sentiments - of meaning and doing - focusing instead on how the regime hoped its future would unfold as it envisioned it contemporaneously, and how it enforced this desire on its subjects.

In an anecdote Speer discussed how he came to his famous theory of "Ruin Value" during the initial stages of the Zeppelinfeld's construction. While crews demolished a nearby building, Speer became aware of the mangled iron framework of the relatively modern structure's corpse. He wrote,

The idea was that buildings of modem construction were poorly suited to form that "bridge of tradition" to future generations which Hitler was calling for. It was hard to imagine that rusting heaps of rubble could communicate these heroic inspirations which Hitler admired in the monuments of the past. My "theory" was intended to deal with this dilemma. By using special materials and by applying certain principles of statics, we should be able to build structures which even in a state of decay, after hundreds or (such were our reckonings) thousands of years would more or less resemble Roman models. ${ }^{127}$

From the outset of the monumental building program there was an emphasis on the use of architecture as a means of connecting the regime to its own history. Citing an article in Das Schwarze Korps written by Himmler, Paul Jaskot argues that architecture also helped bridge the gap between past and future in more immediate, contemporary circumstances. In the article Himmler compares the

\footnotetext{
126 Umbach, 337.

127 Speer, Inside the Third Reich. 56.
} 
supposedly Germanic medieval castles of the occupied east to an historic tradition of military construction. Himmler wrote, "By means of the stone, great epochs speak to the present so that fellow citizens [...] are able to uplift themselves through the beauty of self-made buildings. Proud and self-assured, they should be able to look upon these works erected by their own community"128 For the upper echelons of the NS regime architecture offered a means to "speak" with the future. There was both an understanding of the historicity of the regime and a consideration of the future-mindedness of the National Socialism's cultural ideology that could operate through architecture. ${ }^{129}$

The Zeppelinfeld explicitly operated within National Socialism's own eschatological visions, and was designed with ruin as an eventuality. Here again we can see the rhetoric of eternality overridden by thoughts of totalizing destruction. The Zeppelinfeld's design focused on presenting an historically attractive corpse to future generations thousands of years after the end of National Socialism. Important here is the idea of something being after National Socialism. Believing themselves to be the sole bearers of culture and civilization, who would be left to appreciate the ruins of these great works after their creators were destroyed?

In the Ruins of Modernity, Julia Hell discusses the Nazi conception of ruination, and in particular, discusses the audience which was imagined to

\footnotetext{
${ }^{128}$ Himmler, "Deutsch Burgen im Osten." Das Schwarze Korps, January, 1941. As quoted in Jaskot, 114.

${ }^{129}$ Hagen, "The Most German of Towns." 223. ; Taylor, 270-280.
} 
eventually reflect upon the ruins of National Socialism. The idea of a subject viewing the ruins of empire plays heavily into constructs of imperial power and can be identified as, what Hell calls, "imperial ruin gaze." This ruin gaze is fundamentally bound to a duality of perception, and a two-way relationship of comparative identity, integrally wound around "power relations - between one empire and another, between Romans and barbarians, between conqueror and conquered." ${ }^{30}$ Speer's designs operated under an assumption of impending doom fed into by Hitler's megalomaniacal visions of an eternal empire, and whose fascination with Roman antiquity is ever present in the recurring demand for the use of so-called Doric styles. ${ }^{131}$ Scobie notes that Hitler "admired imperial Rome and its efficient militarism, which enabled it to conquer the world. Above all he admired the state architecture of Rome itself, a world capital furnished with monuments that bore everlasting witness to Rome's power and achievements." ${ }^{132}$ Hell argues that the comparisons between National Socialism and Rome appeared numerous times in Nazi academic circles, and that the story of Rome's war with Carthage offered a framework for rhetoric of racial annihilation and history-making. She further states that National Socialism embarked on a path of empire building aware of the terminality of empires, but argued that they also employed a reimagining of themselves and of their situation as ruin gazer to destabilize the relationship between conquered and conqueror,

\footnotetext{
${ }^{130}$ Hell and Schönle, 170.

${ }^{131}$ Brian McLaren, Architecture and Tourism in Italian Colonial Libya: An Ambivalent Modernism (University of Washington Press, 2006), 82-84.

${ }^{132}$ Scobie, 2.
} 
creating "scenarios in which the ruin gazer in the present imagines another ruin gazer like himself looking at the ruins in the future." ${ }^{133}$ She further notes that, "Hitler's and Speer's ultimate goal was to construct an imperial imaginary that keeps the other - the non-German, the non-Aryan - out of sight."134 Speer's Ruin Value was created not only as a means to emulate the past, but to secure the present against the future.

As an imperial regime, National Socialism sought to colonize its future through the curation of apocalyptic narratives, and ultimately to "counter the specter of imperial decline" that was predicted in Oswald Spengler's 1918 book Der Untergang des Abendlandes ("the Decline of the West"), which described the division of civilizations around cultural archetypes and thusly fit into National Socialism's existing rhetoric of racial hierarchies and cultural superiority. ${ }^{135} \mathrm{~A}$ similar act of cultural hegemony was undertaken in the colonial works of Fascist Italy during the late 1930s. As was the case with NS architecture, an obsession with "Doric" styles and the veneer of Roman militarism was prevalent in Italian colonial projects, particularly in Libya, where a great amount of effort was made by occupying Italian forces to preserve the legacy of past Roman conquests, marginalizing local heritages in favour of ones which fit into the Italian's worldview of a newly resurrected Mediterranean empire. ${ }^{136}$ The act of imperial colonization by both regimes occurred not only in the physical space, but in a

\footnotetext{
${ }^{133}$ McLaren, 109.

134 Hell and Schönle, 176.

135 Ibid., 171.

${ }^{136}$ McLaren, 47.
} 
conceptual one as well. Italy constructed administration buildings that appeared as reflections of a reborn imperium that dominated the Mediterranean while Germany envisioned structures whose legacy would outlast their creators. ${ }^{137}$

By situating themselves into their future, Speer and Hitler sought to gain control over potential future ruin gazers, and in-doing so fortified the present against future doom, ensuring that any such future witness would be of a desirably similar cultural likeness to the Nazis of their present. Stefan-Ludwig Hoffmann states that, "early post-war images by German photographers exhibit a marked allegorical tendency. In the photographs of Friedrich Seidenstücker, Willi Saeger and Willy Römer, to name a few, the defeat and destruction of the city appears as an ancient, far-away world, like the ruins of Pompeii." ${ }^{138}$ When the time came to test the regime's fortifications, the post-war images generated out of Nazism's defeat portrayed the ruins of Berlin within the familiar framework of the "Doric."

Beyond the use of ruination and the future-sighted imperial gaze, National Socialism's coopted rhetoric functioned to shape perceptions of a post-ruin future. Having adopted many of the Church's existing teachings and temporal ideas, the NSDAP cultivated, what Reinhart Koselleck calls, "a history of expectations ... the constant anticipation of the End of the World on the one hand and the continual deferment of the End on the other." ${ }^{139}$ Here Koselleck

\footnotetext{
137 Ibid., 35

${ }^{138}$ Stefan-Ludwig Hoffmann, "Gazing at Ruins: German Defeat as Visual Experience," Journal of Modern European History 9, no. 3 (2011): 328-50, 340.

139 Koselleck, 11.
} 
describes how Christianity understood time, particularly the basic foundations of eschatology, however we can draw parallels to National Socialism's specific temporal perception as well. The end, Koselleck argues, remained a distant and indeterminate eventuality that served as a rhetorical tool to reinforce social power structures; the regime understood that the end would happen but could present itself as being powerful enough, with a culture fortified against the end, to be the sole entity capable of surviving. Important to the Church's conception of time is that the end of the world is not placed in a definite end point of history, or even of time. The end of time is only something one might experience because it is prophesied, requiring a leap of faith. This strengthens the impulse to seek salvation from official channels, and in National Socialism this same mode of thinking was used to augment the historic understanding of the regime, and via it, it's right to rule. ${ }^{140}$ Just as this rhetoric was used by the Church for purposes of strengthening institutional power, so too did National Socialism employ its own narrative of futurity to cement its ideological hold over the population. Likewise, as those that devoutly followed the Church were not necessarily aware or concerned with the Church's power structures and so followed this line of thinking as an expression of divine worldview, so too did the culture of National Socialism promote a civic engagement focused on strengthening the racial and social community.

140 lbid., 11-13. 
In search of a specific answer to the question of who would remain to view National Socialism's monumental ruins there were two paths to the same answer. On the one hand we can envision National Socialism as employing the coopted rhetoric of impending eschaton as a means of re-imagining their own cultural virility and persistence of socio-cultural values beyond the approaching doom, and on the other we can see, specifically, the architectural works of Hitler and Speer as a tool to combat the systemic terminality of empire by ensuring that their own cultural values would remain as the desired norm after their own destruction.

The Reichsparteitagsgelände functioned as a space of great importance in the development of National Socialist cultural ideology. As the seat of the regime's major political rallies the Reichsparteitagsgelände was more than a built environment awaiting cataclysm, it was an active space of cultural engagement. ${ }^{141}$ While the structures served a basic function in the facilitation of the rallies, they were also designed to operate alongside the regime's more fantastical cultural expressions. ${ }^{142}$ Speer's famous Lichtdom (Cathedral of Light) at the 1934 Party Rally turned the arguably gaunt stonework of the Zeppelinfeld into a great spectacle of light and emotion. Figure 4 depicts the Lichtdom as it would have been seen from the Zeppelinfeld grandstands. To create the spectacular effect Speer used over 130 military searchlights. ${ }^{143}$ Directed

141 Schmitz, Matthias. A Nation Builds :contemporary German Architecture. New York, N.Y. : German Library of Information, 1940, 61.

142 Hagen and Ostergren, 157-159.

${ }^{143}$ Fiss, 183. 
upwards, the searchlights created a virtual cage around the Zeppelinfeld, encircling the whole rally in a stark fortification of pure light. The use of military searchlights in the production meant that the Lichtdom offered audiences two very powerful messages. To local spectators, the Lichtdom represented National Socialism's monolithic power and cultural strength, a power that called upon spiritual imagery and used technology and human will to literally pierce the heavens. ${ }^{144}$ To outside observers the message was much more politically calculated. After hearing of Speer's request for 130 searchlights, Goering adamantly fought to reduce the number as Speer's project would require an unrealistic portion of the nation's strategic reserves. According to Speer, Hitler rebuffed Goering by stating, "If we use them in such large numbers for a thing like this, other countries will think we're swimming in searchlights." ${ }^{145}$ The cultural expression of the Lichtdom became a means of projecting the state's power abroad as well as amongst its own followers. In addition to its hosting of the Lichtdom, the Zeppelinfeld was the focus of other artistic expressions: the artist Erich Mercker painted several illustrations of the Reichsparteitagsgelände's structures, including the construction of the Kongresshalle and a depiction of Speer's Lichtdom. ${ }^{146}$ Other artists, like Rudolf Hengstenberg, presented the architectural works associated with National Socialism as part of an elysian Volkisch paradise, complete with Germanic agrarian iconography and crowds of

\footnotetext{
144 Hagen and Ostergren, 163.

145 Speer, Inside the Third Reich, 58-59.

${ }^{146}$ Erich Mercker, Reichsparteitag, in Fiss, 85.
} 
dutiful National Socialists whose throngs give the appearance of grain waving in the breeze. ${ }^{147}$ The Reichsparteitagsgelände is arguably the most well known sites of National Socialist architecture, particularly as it is one of the only sites where completed projects still exist and because it is one of the foundations spaces in development of the NSDAP's monumental architecture program. Alongside Nuremberg, the regime also sought to explore its architectural possibilities in Berlin, specifically, in the shaping of the city into a grandiose regional capital whose skyline would, purportedly, be the envy of the world. That Berlin and Nuremberg are the foci of this project is a reflection of both Hitler's willingness to provide for his pet projects in Berlin and Nuremberg despite mounting war costs, as well as the grand nature of the plans for those cities. ${ }^{148}$

\footnotetext{
147 Rudolf Hengstenberg, Maifeier im Lustgarten, Berlin, in Fiss, 94-95.

148 Jaskot, 26. ; Macdonald, Difficult Heritage. 27. ; Gavriel David Rosenfeld and Paul B. Jaskot, Beyond Berlin: Twelve German Cities Confront the Nazi Past (University of Michigan Press, 2008), 144.
} 


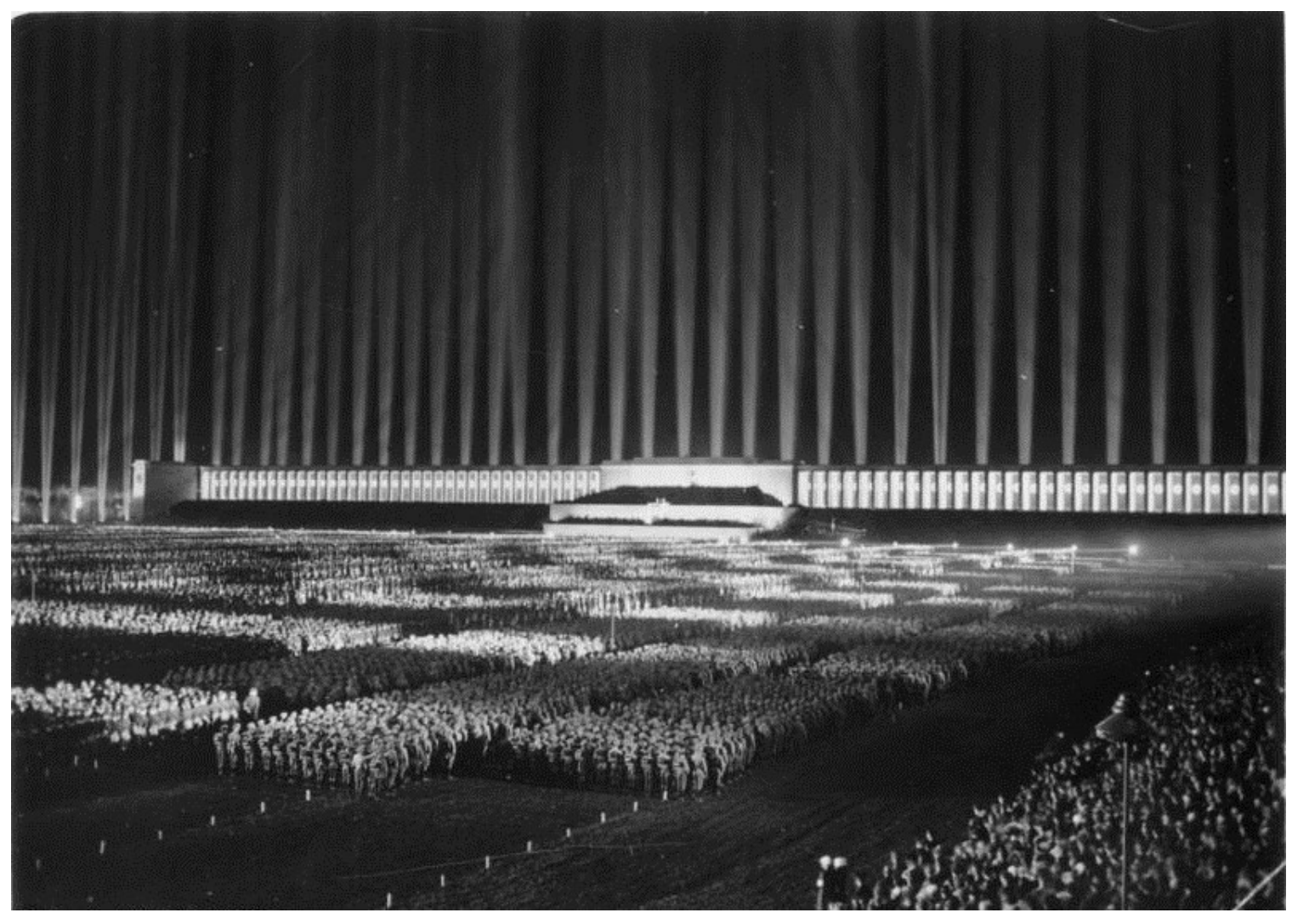

Figure 4 - The Zeppelinfeld illuminated to form Speer's Lichtdom. [Bundesarchiv Bild 183-1982-1130-502, Nürnberg, Reichsparteitag, Lichtdom]

Both the second and third sites I discuss are located in Berlin, the first of which is the Reichssportfeld in the Charlottenburg-Wilmersdorf district of Berlin. Unlike the Zeppelinfeld, the Reichssportfeld was constructed before Speer's theory of Ruin Value was established, however the implications of the structure's use of ancient imagery suggest an anticipation of a future ruin gazer that predates Speer's architectural epiphany. As well, the Reichssportfeld did not make use of such religious symbolism as was present in the Lichtdom. Instead of presenting an envisioned future, this building presented a tangible continuity 
between the greatness of the past and that of the present, with implications of a future to be had. ${ }^{149}$

The Reichssportfeld was home to several buildings built before the NSDAP took power, however the most important for this discussion is the Olympiastadion. The Olympiastadion was built to host the Olympic games, however the organizers were not certain which year the games would visit. The project underwent several revisions, and eventually became entangled in a logistical and financial quagmire. ${ }^{150}$ Progress on the stadium was delayed until October 1933 when Hitler, as the newly appointed chancellor, visited the site and dictated that the stadium be completed to his specification, with the Reich taking on the existing fiscal burden. ${ }^{151}$ The new stadium was built over the existing Grunewaldstadion which had been used primarily for horse racing in its early days. ${ }^{152}$ The stadium was named for its location in the historically wealthy Berlin suburb situated around the Grunewald forest. ${ }^{153}$ The renovated Olympiastadion was designed by architect Werner March who produced a large, Neoclassically inspired structure. Built in resemblance of the Colosseum, the Olympiastadion clearly evoked antiquity in its use of columns and stonework. ${ }^{154}$ Taylor discusses

\footnotetext{
149 Joshua Hagen, "Parades, Public Space, and Propaganda: The Nazi Culture Parades in Munich," Geografiska Annaler: Series B, Human Geography 90, no. 4 (2008): 359.

150 Mario Kessler, "Only Nazi Games? Berlin 1936: The Olympic Games between Sports and Politics," Socialism and Democracy 25, no. 2 (July 2011): 125.

151 Organisationskomitee für die XI. Olympiade Berlin 1936 E. V., The 11th Olympic Games Berlin, Germany- Official Report vol.1.133-135.

152 Grunewaldstadion (Berlin, Berlin: Olympiastadion-Berlin, n.d.) information panel

${ }^{153}$ Barry A. Jackisch, "The Nature of Berlin: Green Space and Visions of a New German Capital, 1900-45," Central European History 47, no. 2 (June 2014): 324.

154 Speer, Inside the Third Reich, 80.
} 
the stadium in terms of its use of what he calls "community architecture," an aesthetic that played into the community-building, racialized ideology of the regime. ${ }^{155}$ Traditionally the structure is described as Neoclassical, and certainly there is an attempt to evoke the spirit of antiquity, however it would be preferable to contextualize this architecture within National Socialism's vision of temporality. ${ }^{156}$ The Olympiastadion hearkens back to antiquity, yes, but its aesthetic goes beyond the mimicry of 19th century European artistic fancy. Instead, we can consider this project, as with the Zeppelinfeld, to employ a style of continuity. There is more to the outward appearance than the recognizable classicism. ${ }^{157}$

In addition to the stadium itself the complex also hosted the imposing Langemarck-Halle and accompanied bell tower, which stood on the Maifeld. As the name suggests, the Langemarck-Halle housed tributes to the German soldiers who fought in the First World War battle of Langemarck. ${ }^{158}$ In the attached Glockenturm (bell tower) the National Socialists installed a commemorative bell for the 1936 Olympic games. ${ }^{159}$ These buildings and the Maifeld are situated next to the Olympiastadion and form the bulk of the complex's grand structures. The NSDAP's reconstruction of the Reichssportfeld

\footnotetext{
155 Taylor, The Word in Stone, 160.

156 Jaskot, 17.

157 Hans Bonde, "Danish Sport and the Nazi Seizure of Power: Indoctrination, Propaganda and Confrontation," The International Journal of the History of Sport 26, no. 10 (August 2009): 14611463; Jaskot, 84.

${ }^{158}$ Langmarck-Halle (Berlin, Berlin: Olympiastadion-Berlin, n.d.) information panel.

159 Langmarck-Halle Glockenturm (Berlin, Berlin: Olympiastadion-Berlin, n.d.) information panel.
} 
was one of the earliest instances of party historicity manifest in completed architecture. ${ }^{160}$ As an early example of the regime's architecture, one which predated Albert Speer and his future-sighted structures, the Reichssportfeld was primarily an evocation of the regime's desire for an idealized past. ${ }^{161}$ Like the Zeppelinfeld's Lichtdom however, the Reichssportfeld was also an active site of historicity. The Olympic Games, themselves an attempt to reclaim the glory of ancient times, were held there in 1936, however Hitler had mentioned that his own national Kampfspiele (competitive games) might one day replace the Olympics, ensuring that Germany would play host to all future games. ${ }^{162}$ While the physical structures emphasized the past, the purpose they fulfilled was part of the future-oriented culture of National Socialist hegemony. ${ }^{163}$ In the distant future imagined for National Socialism, the once international competition would be replaced with the strictly national Kampfspiele which would be played in a structure built to commemorate the regime's imagined past, in a world envisioned exclusively for National Socialism. The co-option of the Olympics is a testament to the vision that the NS leadership had for the future of the movement. The manipulation of the games was not the only purpose that the Reichssportfeld served in the curation of a Nazi future. Additionally, the remodeling of the

\footnotetext{
160 Gerdy Troost, Das Bauen Im Neuen Reich, vol. 1 (Gauverlag Bayreuth, 1943),49.

${ }^{161}$ Michael Mackenzie, "From Athens to Berlin: The 1936 Olympics and Leni Riefenstahl's Olympia," Critical Inquiry 29, no. 2 (January 2003): 316-317.

162 Hitler and Domarus, 852.

${ }^{163}$ Bonde, 1461.
} 
Olympiastadion was the first of several large-scale redesigns that featured as part of the grand plans for the envisioned Welthauptstadt Germania.

The final site of interest is the Schwerbelastungskörper in the Tempelhof district of Berlin. Unlike the structures of the Reichsparteitagsgelände or the Reichssportfeld, the Schwerbelastungskörper is representative of the largely unrealized yet heavily future-sighted projects of National Socialism. It was the only significant physical piece of the grander proposed Welthauptstadt Germania to be completed. The structure was erected in 1941 as a means of testing the viability of the planned Triumphal Arch, which was to be constructed nearby. The final conclusion made by the construction engineers was that the land surrounding the site would not be able to support the massive weight of the arch. ${ }^{164}$ Despite this, orders to proceed with the construction were given, and only after the onset of the war with the Soviet Union, and the corresponding change in priorities, were plans for the new Berlin permanently abandoned. ${ }^{165}$ Welthauptstadt Germania was the proposed rebuilding of Berlin into a city that the NSDAP deemed worthy of being the "world capital." The plans called for the complete redesign of the city's central core along a new major axis that ran north-south from the Reichstag to northwestern Tempelhof. This new avenue was to be called the Prachtallee ("Boulevard of Splendours") and was to be lined

${ }^{164}$ Schwerbelastungskörper (Berlin, Berlin: Museen Tempelhof-Schöneberg, n.d.) information panel.

165 Speer, Albert Speer, 68. 
with dozens of new structures to showcase the NSDAP's glory and power. ${ }^{166}$ The Prachtallee was to begin at the site of the former Reichstag in a large open area Speer called the Großer Platz ("Grand Place"), which would have been erected on the existing Königsplatz. ${ }^{167}$ This gathering space would be surrounded on all sides by monumental structures, including the Große Halle ("Great Hall") ${ }^{168}$, Führerpalast ("Führer Palace"), new Reich Chancellery, OKW ${ }^{169}$ headquarters, and the redesigned Reichstag. The Prachtallee then stretched south terminating at the impressive Reichsbahn station that was to act as the city's central rail transport hub. The southern end of the Prachtallee passed near Tempelhof airport and was generally planned to be the hospitality sector of the new city, sporting various theaters, opera houses, small arenas, hotels, and of course a direct rail link to the Reichssportfeld. ${ }^{170}$ At the southern termination of the Prachtallee there was a section of the avenue dedicated to the Reich's military victories. Captured artillery would line the streets, and passengers traveling along the Prachtallee would have to pass under the massive Triumphal Arch that Hitler and Speer had planned would commemorate the dead of the First World War. ${ }^{171}$ Emulating the style of Paris' Arc de Triomphe, this structure was to be built to several times the scale. ${ }^{172}$ Speer noted, "Our triumphal arch, five hundred and

\footnotetext{
166 Julia Walker, "Capital Building: Anxiety and Memory in Berlin's Government District" (Ph.D., University of Pennsylvania, 2009), 21.

${ }^{167}$ Friedrich, 369.

168 Sometimes also referred to as the Volkshalle ("People's Hall").

169 Oberkommando der Wehrmacht (Supreme Command of the Armed Forces)

170 Speer, Albert Speer. 56-57.

${ }^{171}$ Friedrich, 351.

172 Jackisch, 319.
} 
fifty feet wide, three hundred and ninety-two feet deep, and three hundred and eighty-six feet high, would have towered over all the other buildings on this southern portion of the avenue and would literally have dwarfed them." ${ }^{173}$ It was for this building that the Schwerbelastungskörper was a test. In a moment of typical NS vision, the project was given the go-ahead despite a serious failure of foundation stability tests: if the Schwerbelastungskörper sank less than $6 \mathrm{~cm}$, then the ground would be stable enough to support the monumental arch Hitler desired. ${ }^{174}$ The test was a complete failure, however, and the structure sank well beyond that, with estimates suggesting a lowering of nearly $20 \mathrm{~cm}$ within the first few years. ${ }^{175}$

\footnotetext{
173 Speer, Inside the Third Reich. 135-136.

${ }^{174}$ Friedrich, xiii.

${ }^{175}$ Schwerbelastungskörper (Berlin, Berlin: Museen Tempelhof-Schöneberg, n.d.) information panel.
} 


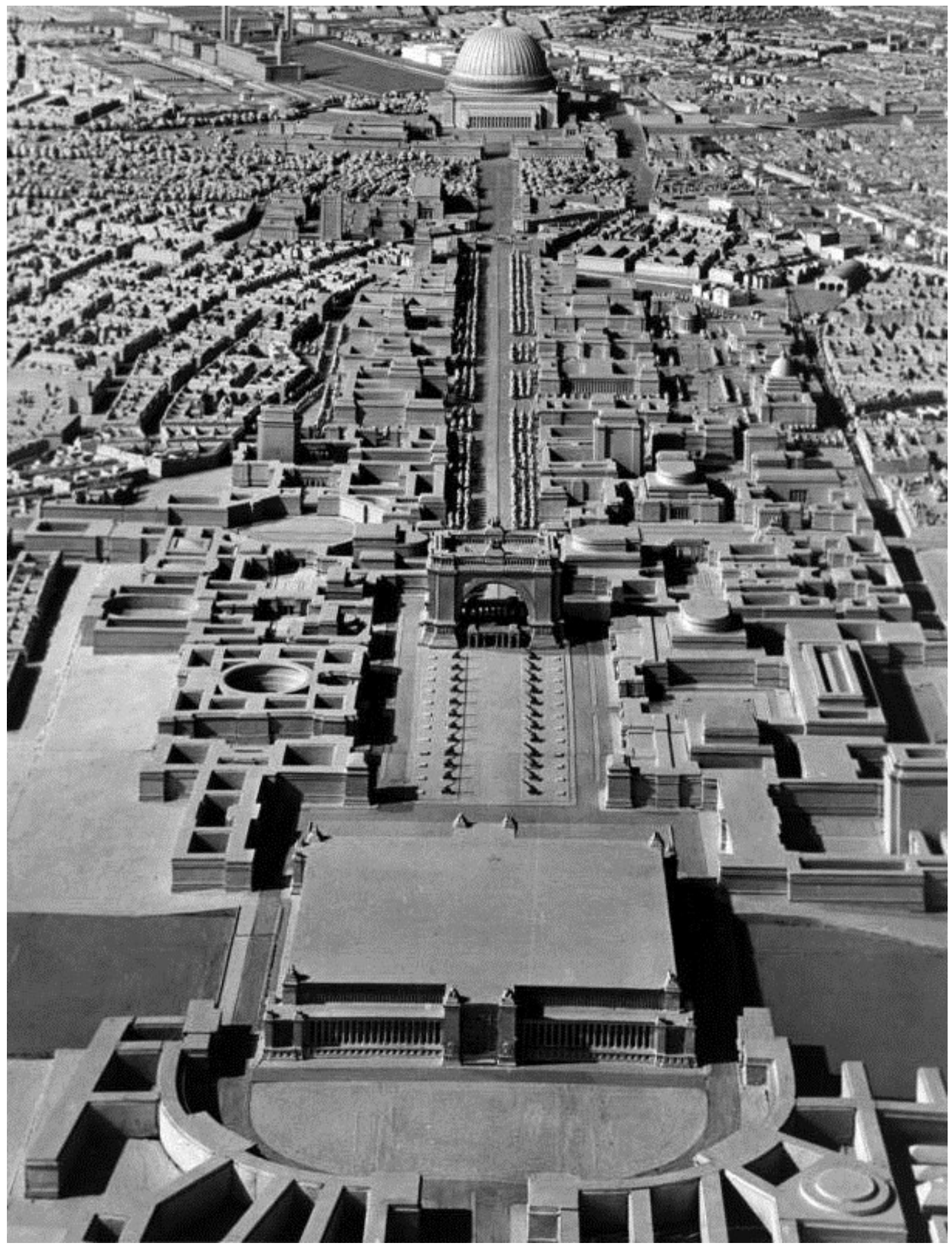

Figure 5 - A model of the proposed Welthauptstadt depicting the Prachtallee with the domed Große Halle at top, Triumphal Arch at center, and the Reichsbahn station at bottom. [Speer Architecture, 53] 
The Welthauptstadt plans are often cited as one of the NSDAP's more fantastical and megalomaniacal dreams. ${ }^{176} \mathrm{I}$ argue that it is perhaps more productive to view the NSDAP's proposed rebuilding of Berlin as an unrealized example of the regimes fascination with the future and its own continuity. The plans for the Welthauptstadt appear to the modern viewer as if from a work of science fiction, with the Große Halle being the most noteworthy example of this otherworldly style The Große Halle was planned to be a structure truly deserving of the title "monumental": designed to fill the role of a medieval meeting hall, but scaled up several hundred times: ${ }^{177}$ it was a place of civil order and of devout worship to National Socialism. ${ }^{178}$ The main meeting space was to be covered by an enormous dome that would reach an internal ceiling of 220 meters. ${ }^{179}$ Speer's sketches and drafts depict the building as heavily reliant on quasi-Roman styles blended with both vernacular and modern materials. ${ }^{180}$ This blending of styles was proposed for most of the individual structures envisioned as part of the greater plan for Welthauptstadt Germania: a combination of modern materials, Neoclassical imagery, and Volkisch implications. Joshua Hagen notes that, in the example of the Munich Königsplatz, the redesign presented a clash of ideological considerations. While the plans to maintain that space fulfilled the desire for

\footnotetext{
${ }^{176}$ Arnold Bartetzky, "Changes in the Political Iconography of East Central European Capitals after 1989 (Berlin, Warsaw, Prague, Bratislava)," International Review of Sociology 16, no. 2 (July 2006), 452; Bonde, 1462 ; Hagen, "Architecture, Symbolism, and Function", 418; Jackisch, 319; Jaskot, 103; Macdonald, Difficult Heritage, 26-28.

177 Speer, Inside the Third Reich. 74.

178 Ibid., 152.

179 Speer, Albert Speer. 77.

180 lbid., 63-83.
} 
balance and harmony with the planned additional structures, its muted scale was in opposition to the equally strong desire for monumentalism. ${ }^{181}$ As a test project for further urban redesigns, including Berlin, the Munich Königsplatz was still envisioned to function within NS temporality: the space was designed with temples dedicated to the regime, in which heroes to the movement were interred, making the Königsplatz, "an integral component of future commemoration." 182 In Berlin, this drive toward the grandiose was more predominant as the city was not only the capital of the new Reich, but was designed as the hub of culture and administration for the future world culture bearers. ${ }^{183}$ Other notable projects - the Führerpalast, the OKW headquarters, and the greatly expanded S-Bahn station all matched the Große Halle in spectacle if not in size.

As with the Zeppelinfeld, the structures of Welthauptstadt Germania were constructed following the tenets of Speer's "Theory of Ruin Value," and were built with the regime's Götterdämmerung ${ }^{184}$ in mind. The name of this new Berlin is indicative of the future that was envisioned for the Reich: as leaders of a new world order in which Berlin would serve as the center of political, social, and cultural life for as long as the regime lasted. ${ }^{185}$ In the event of the regime's destruction, this massive urban center would leave ruins that overshadowed the

\footnotetext{
181 Hagen, "Architecture, Symbolism, and Function," 408-411.

182 Ibid., 413.

183 Jackisch, $317,319$.

184 Götterdämmerung is the name of a Wagnerian epic in which the world is burned, consumed, and reborn.

185 Josef K. Glowa, "The Search for National Identity in Abstractions From Historical Images: A German Example,” Comparative Civilizations Review, no. 64 (2011): 6., 8.
} 
entirety of antiquity and would cement National Socialism in the annals of history as the foremost civilization of its time. The progress of this momentous project was ultimately halted on the outset of war with the Soviet Union. In his memoirs Speer reflects upon his designs for Berlin and appears fascinated with the similarities between his designs and those of the twilight of various historic empires. Whether this is sincere or part of Speer's self-serving teleological attitude toward his past is questionable, however his statement still rings true. The structures designed to herald in National Socialism's triumphant future would ultimately be the final cultural gasps of a regime on the decline.

In this chapter I have examined the development of German architecture as it relates to a cultural sense of time and history, indicating where architecture fit into existing temporal understandings. I have examined three sites of National Socialist architecture as they relate to National Socialism's larger framework of temporal identity and historicity. Specifically, I argue that these three sites - the Reichsparteitagsgelände, Reichssportfeld, and Welthauptstadt Germania represent the regime's attempts to express in tangible form its own desires for evidence of its own continuity and right to exist, a right that was imagined to extend beyond the present into the past and future, and across the entirety of the National Socialism's conception of history. 


\section{Conclusion - Unanticipated Ruin}

National Socialist architecture - devised under the mindful eye of Hitler and Speer, influenced by the ideologies of Rosenberg, Darré, Ley, and von Schirach, and framed within existing historic myths - was unique in its participation within a greater cultural narrative of temporality. Through a process of creation and co-option of cultural entities and systems, the NSDAP and its foremost ideologues produced a culture within National Socialist society that looked to the future as a space of active engagement. The authority of temporality in NS rhetoric drove the regime to co-opt and reimagine existing socio-cultural institutions, as well as create future-oriented myths that imagined the National Socialist movement as belonging to a larger narrative of historic significance. In this regard, existing religious systems offered the regime an ideal platform upon which to construct an ideology of far reaching potential and a legacy that offered imagery of both doom and paradise. Acting within this ideology the Nazis employed architecture not only as a means to project their own current power and worldview, but also to combat ideological fears of their eventual demise as a civilization. By borrowing from religious iconography and rhetoric of apocalypse, and by promoting the regime's own historic and eternal qualities, orators and propagandists were able to instill within the movement a sense of futurity and certainty which permeated all aspects of life in the Third Reich: from festivals, to speeches, to games, and even into the everyday 
parlance of its citizens. It was within this conflicting worldview of eternality and doom that the monumental structures proposed by Hitler and Speer were designed to function.

The buildings of the Reichsparteitagsgelände, Reichssportfeld and the proposed site of Welthauptstadt Germania were each envisioned within a cultural narrative that emphasized a duality of anticipated destruction and noble perpetuity. The creation of this architecture was likewise the creation of objectivelieux de memoire with which the regime could expand their cultural authority beyond the boundaries of their present, into the future. By projecting current cultural and ideological messages onto an imagined future, NS architecture was predicted to provide both imperial ruins and social building blocks to a desired future "ruin gazer," whose own cultural inclinations would match those of the ruin's builders. These sites then represent surviving, tangible works produced as part of NS temporal rhetoric, and offer a means of interrogating NS temporality beyond that of speeches and propaganda. However, while these sites do present physically accessible lieux de memoire, the future in which they were designed to operate, and the audience that was imagined to witness them, do not exist. The regime's imagined cultural hegemony collapsed with the fall of National Socialism.

In this project I explored the literature's current discussions on NS architectural temporality, arguing that more emphasis needs to be placed on the relationship between the party's sense and expression of culture and notions of 
time and historicity. Specifically, I argue that where scholars have identified NS desires for longevity and fears of terminality as well as the relationship of these feelings to architecture, there is still more work needed in framing these desires as part of a greater narrative of temporality, one which permeated all aspects of National Socialist cultural life. I presented examples of NS attempts to foster this narrative, including the aforementioned religious institutions, as well as the infiltration of the historisch into everyday speech, and adoption of purportedly historically-inclined ideology of racial heritage. Finally, I contend that the three sites discussed offer discernable examples of the regime's obsession with its own future and its desire to create physical tools to manipulate this future.

I propose that my work represents the first steps in a larger project which seeks to explore the intent behind the production of these structures. Going forward, any work that would expand on this project would need to more closely examine the personal sentiment of those involved in the creation of these structures, not only at the highest levels of the regime's ideologues, but also those participating in the logistics and practical design of the structures. Any such project would also need to focus on how these people understood their work as actively - or perhaps passively - participating in the continuation of the regime's cultural narrative. Noting again Maiken Umbach emphasis on examining what National Socialism "meant to people, rather than what it tried to do to people," 186 the continuation of this project would explore the threshold between

186 Umbach, 337. 
what the regime intended - what it attempted to do - and what those participating in this project actually felt - what it meant to them. This project emphasizes the act of desire and intent rather than result and outcome, however any future work would need to incorporate analysis of the latter - situated alongside the works of historians who have already plied this avenue of interrogation - and present the monumental structures of National Socialism both as they were intended to function, and how they are presently received, as relics of a failed and notorious regime.

Ultimately the projected future in which these structures would triumphantly herald the persistence of Nazi culture never came to pass. On April 30th, 1945 Hitler committed suicide in the bombed-out ruins of Berlin. On May 23rd, 1945, Albert Speer was arrested along with the remaining members of the NSDAP's government. Speer spent 20 years in Spandau prison for his involvement with the Nazis and was barred from practising architecture for some time after his release. The surviving works of monumental architecture built by the Nazi regime were gradually destroyed and left to ruin. The regimes most notable remaining work, the Zeppelinfeld, exists today as a testament to the failed grandeur of the Third Reich: its dilapidated and unimposing form tucked away behind a caravan campground and local park, visited by the occasional tourist and Norisring spectator. 


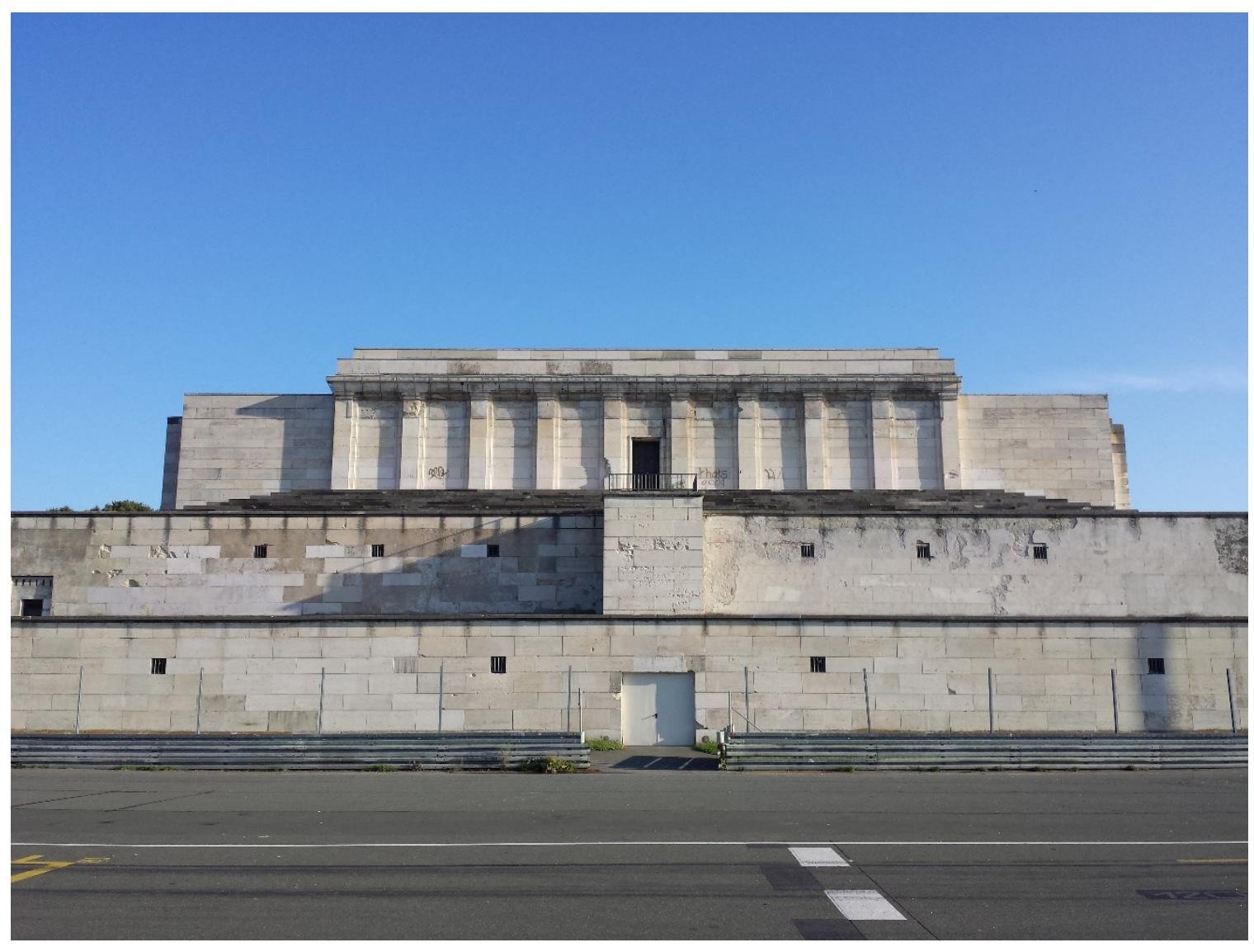

Figure 6 - The start line of the Norisring in Nuremberg featuring the ruins of the Zeppelinfeld [Alex Wilkinson, October 2014] 


\section{Bibliography}

\section{Primary Material}

"Decisive Battles - Battles of Annihilation." Zeitschriften-Dienst, October 31, 1941.

"Er ist der Sieg." Das Schwarze Korps, April 20, 1944.

Goebbels, Joseph. “Das Jahr 2000.” Das Reich, February 25, 1945.

—. "New Year Address for 1939," 39-12 1938.

"Nun, Volk steh auf, und Sturm brich los! Rede im Berliner Sportpalast." In Der steile Aufstieg, 167-204. Munich: Zentralverlag der NSDAP, 1944.

Göring, Herman. "Untitled Editorial." Sommerlager-und Heimabendmaterial für Schulungs-und Kulturarbeit, Summer 1941.

H. Mehringer. "Sieg des Glaubens. zum 30. Januar." Der Schulungsbrief, January 30, 1939.

Hitler, Adolf, and Max Domarus. Speeches and Proclamations, 1932-1945. Wauconda, IL, U.S.A: Bolchazy-Carducci, 1990.

Hitler, Adolf, and Abraham Foxman. Mein Kampf. Translated by Ralph Manheim. 20th edition. Boston: Houghton Mifflin, 1999.

"Kennst du sie? ...die Daten der Deutschen Geschichte ('Do You Know That?')," 1940.

Schmitz, Matthias. A Nation Builds: Contemporary German Architecture. New York, N.Y. : German Library of Information, 1940.

Speer, Albert. Albert Speer: Architecture, 1932-1942. Bruxelles: Archives d'architecture moderne, 1985.

—. Inside the Third Reich. 1 edition. New York: Simon \& Schuster, 1997.

Troost, Gerdy. Das Bauen im neuen Reich. Vol. 1. Gauverlag Bayreuth, 1943.

Winckelmann, Johann Joachim, and Henry Fuseli. Reflections on the Painting and Sculpture of the Greeks: With Instructions for the Connoisseur, and an Essay on Grace in Works of Art. London: Printed for the Translator, and sold by A. Millar, 1765. 


\section{Secondary Material}

Adam, Peter. Art of the Third Reich. New York: H.N Abrams, 1992.

Arnold, Bettina. "'Arierdämmerung ': Race and Archaeology in Nazi Germany." World Archaeology 38, no. 1 (March 2006): 8-31.

Bartetzky, Arnold. "Changes in the Political Iconography of East Central European Capitals after 1989 (Berlin, Warsaw, Prague, Bratislava)." International Review of Sociology 16, no. 2 (July 2006): 451-69.

Bergen, Doris L. "'Germany Is Our Mission-Christ Is Our Strength!' The Wehrmacht Chaplaincy and the 'German Christian' Movement." Church History: Studies in Christianity and Culture 66, no. 3 (1997): 522-36.

Bonde, Hans. "Danish Sport and the Nazi Seizure of Power: Indoctrination, Propaganda and Confrontation." The International Journal of the History of Sport 26, no. 10 (August 2009): 1458-80.

Bytwerk, Randall L. Bending Spines: The Propagandas of Nazi Germany and the German Democratic Republic. East Lansing, Mich: Michigan State University Press, 2004.

Chandler, Albert Richard. Rosenberg's Nazi Myth. Ithaca, N. Y: Cornell University Press, 1945.

Ehrenreich, Eric. The Nazi Ancestral Proof: Genealogy, Racial Science, And the Final Solution. Bloomington: Indiana University Press, 2007.

Fiss, Karen. Grand Illusion: The Third Reich, the Paris Exposition, and the Cultural Seduction of France. Chicago; London: University of Chicago Press, 2009.

Friedrich, Thomas. Hitler's Berlin: Abused City. New Haven: Yale University Press, 2012.

Glowa, Josef K. "The Search for National Identity in Abstractions from Historical Images: A German Example." Comparative Civilizations Review, no. 64 (2011): 6.

Hagen, Joshua. "Architecture, Symbolism, and Function: The Nazi Party's 'Forum of the Movement." Environment and Planning D: Society and Space 28, no. 3 (June 2010): 397-424. 
_. "Parades, Public Space, and Propaganda: The Nazi Culture Parades in Munich." Geografiska Annaler: Series B, Human Geography 90, no. 4 (2008): 349-367.

- "The Most German of Towns: Creating an Ideal Nazi Community in Rothenburg ob der Tauber." Annals of the Association of American Geographers 94, no. 1 (2004): 207-27.

Hagen, Joshua, and Robert Ostergren. "Spectacle, Architecture and Place at the Nuremberg Party Rallies: Projecting a Nazi Vision of Past, Present and Future." Cultural Geographies 13, no. 2 (2006): 157-181.

Hell, Julia, and Andreas Schönle. Ruins of Modernity. Duke University Press, 2010.

Herbert, James D. Paris 1937: Worlds on Exhibition. Cornell University Press, 1998.

Heschel, Susannah. The Aryan Jesus: Christian Theologians and the Bible in Nazi Germany. Princeton University Press, 2008.

Hochman, Elaine S. Architects of Fortune: Mies van Der Rohe and the Third Reich. 1st ed. New York: Weidenfeld \& Nicolson, 1989.

Hoffmann, Stefan-Ludwig. "Gazing at Ruins: German Defeat as Visual Experience." Journal of Modern European History 9, no. 3 (2011): 328-50.

Jackisch, Barry A. "The Nature of Berlin: Green Space and Visions of a New German Capital, 1900-45." Central European History 47, no. 2 (June 2014): 307-33.

James, Kathleen. Erich Mendelsohn and the Architecture of German Modernism. Modern Architecture and Cultural Identity. Cambridge, U.K. ; New York, NY, USA: Cambridge University Press, 1997.

- German Architecture for a Mass Audience. London; New York: Routledge, 2000.

Jaskot, Paul B. The Architecture of Oppression: The SS, Forced Labor and the Nazi Monumental Building Economy. The Architext Series. London; New York: Routledge, 2000.

Kershaw, lan. The "Hitler Myth": Image and Reality in the Third Reich. Oxford: New York: Clarendon Press; Oxford University Press, 1987.

Kessler, Mario. "Only Nazi Games? Berlin 1936: The Olympic Games between Sports and Politics." Socialism and Democracy 25, no. 2 (July 2011): 125-43. 
Klemperer, Victor, and Martin Brady. The Language of the Third Reich: LTI - Lingua Tertii Imperii: A Philologist's Notebook. London; New York: Continuum, 2002.

Koselleck, Reinhart. Futures Past: On the Semantics of Historical Time. Translated by Keith Tribe. New York: Columbia University Press, 2004.

Kurtz, Angela Astoria. "God, Not Caesar: Revisiting National Socialism as 'political Religion." History of European Ideas 35, no. 2 (June 2009): 236-52.

Landes, Richard, ed. Encyclopedia of Millennialism and Millennial Movements. New York: Routledge, 2000.

Lane, Barbara Miller. Architecture and Politics in Germany, 1918-1945. Cambridge, Mass: Harvard University Press, 1968.

Lane, Tony. Concise History of Christian Thought, A. Revised edition. Grand Rapids, Mich: Baker Publishing Group, 2010.

Macdonald, Sharon. Difficult Heritage: Negotiating the Nazi Past in Nuremberg and Beyond. Routledge, 2010.

- "Words in Stone? Agency and Identity in a Nazi Landscape." Journal of Material Culture 11, no. 1-2 (July 1, 2006): 105-26.

Mackenzie, Michael. "From Athens to Berlin: The 1936 Olympics and Leni Riefenstahl's Olympia." Critical Inquiry 29, no. 2 (January 2003): 302-36.

McLaren, Brian. Architecture and Tourism in Italian Colonial Libya: An Ambivalent Modernism. University of Washington Press, 2006.

Mosse, George Lachmann. Nazi Culture: Intellectual, Cultural and Social Life in the Third Reich. Univ of Wisconsin Press, 2003.

Nora, Pierre, and Lawrence D. Kritzman. Realms of Memory: Conflicts and Divisions. Columbia University Press, 1996.

Paret, Peter. German Encounters with Modernism: 1840-1945. New York: Cambridge University Press, 2001.

Pine, Lisa. Hitler's "National Community": Society and Culture in Nazi Germany. London: Hodder Arnold, 2007. 
Posener, Julius. From Schinkel to the Bauhaus: Five Lectures on the Growth of Modern German Architecture. Architectural Association. Paper No. 5. London: Lund Humphries for the Architectural Association, 1972.

Rosenfeld, Gavriel David, and Paul B. Jaskot. Beyond Berlin: Twelve German Cities Confront the Nazi Past. University of Michigan Press, 2008.

Scobie, Alexander. Hitler's State Architecture; the Impact of Classical Antiquity. Monographs on the Fine Arts 45. University Park: Pennsylvania State U, 1990.

Steffens, Martin. K. F. Schinkel 1781-1841: An Architect in the Service of Beauty. Taschen, 2003.

Steigmann-Gall, Richard. "The Holy Reich": Nazi Conceptions of Christianity, 19191945. New York: Cambridge University Press, 2003.

Taylor, Brandon, and Wilfried van der Will, eds. The Nazification of Art: Art, Design, Music, Architecture, and Film in the Third Reich. 1st ed. Winchester, Hampshire: Winchester Press, Winchester School of Art, 1990.

Taylor, Robert R. The Word in Stone: The Role of Architecture in the National Socialist Ideology. Berkeley: University of California Press, 1974.

Tenenbaum, Joseph. Race and Reich; the Story of an Epoch. New York: Twayne Publishers, 1956.

Terdiman, Richard. Present Past: Modernity and the Memory Crisis. Cornell University Press, 1993.

Udovički-Selb, Danilo. "Facing Hitler's Pavilion: The Uses of Modernity in the Soviet Pavilion at the 1937 Paris International Exhibition." Journal of Contemporary History 47, no. 1 (January 1, 2012): 13-47.

Umbach, Maiken. "Selfhood, Place, and Ideology in German Photo Albums, 19331945." Central European History 48, no. 3 (September 2015): 335-65.

Van Den Bruck, Arthur Moeller. Germany's Third Empire. Arktos, 2012.

Vieler, Eric H. The Ideological Roots of German National Socialism. McGill European Studies, vol. 2. New York: P. Lang, 1999.

Walker, Julia. "Capital Building: Anxiety and Memory in Berlin's Government District." Ph.D., University of Pennsylvania, 2009. 
Watkin, David, and Tilman Mellinghoff. German Architecture and the Classical Ideal. 1st MIT Press ed. Cambridge, Mass: MIT Press, 1987.

Whyte, lain Boyd. "Charlottenhof: The Prince, the Gardener, the Architect and the Writer." Architectural History 43 (2000): 1.

Wiedenhoeft, Ronald. Review of Review of The Word in Stone: The Role of Architecture in the National Socialist Ideology, by Robert R. Taylor. Journal of the Society of Architectural Historians 34, no. 2 (1975): 157-59. 